\title{
AXUDANDO A RESTAURAR A CASA COMÚN. LOIS TOBÍO NO GALEGUISMO DA POSGUERRA
}

Carlos Méixome

Profesor retirado

Instituto de Estudos Miñoráns

DOI: 10.17075/ltgtx.2020.002 



\section{ADRO}

«Foi fermoso vivir coa ilusión de estar axudando a restaurar a vella casa común, encanastrada por alleos e alleeiros, para despois enriquecela con novas construccións» Así comeza o último parágrafo de As décadas de T. L., nas que Tobío exerce a súa memoria, relata a súa autobiografía, realiza as súas confesións e amosa, con rotunda vitalidade, a satisfacción por ter andado o "camiño xusto», como lle gustaba dicir. O parágrafo continúa coa ilusión desbordada «vendo con gozo como sigue a traballar e loitar a xente moza na mesma dirección, a que sinalaron os nosos devanceiros desde o Rexurdimento». Entre esa xente moza á que se refire Tobío estaba o meu amigo Emilio Ínsua, co que estou encantado de compartir este relato sobre o galeguismo de Tobío.

Ese vitalismo estoura ao escoller a derradeira liña da súa derradeira grande achega á casa común, concluíndo, cun dos seus grandes mestres, Goëthe: «Tal como é, a vida é boa» ${ }^{1}$. Un vitalismo e un camiñar que recoñecemos na súa novela curta $A$ nova vida. Probablemente rematada no comezo da esperanza que comeza tras a tráxica derrota, militar e política, que se prolongaría durante anos en forma de case eterno exilio. Nesta achega póstuma súa, de necesaria lectura en clave sociolóxica, tan do seu gusto, evidénciase unha redacción inicial e unhas preocupacións propias de tempos prebélicos e de formación do nacionalismo galego a través da historia dun Antón, apoucado membro dunha familia fidalga

\footnotetext{
1 Tobío, L. (1994): As décadas de T. L., Sada (A Coruña), Ediciós do Castro, p. 702.
} 
minorada, de quen nin sabemos o apelido, que decide loitar por mudar a situación á que o teñen sometido "os de fóra» (arrieiros maragatos, coireiros vascos, salgadores cataláns) e "os de arriba» (burgueses de pluma e comercio) e ser el mesmo. Nesta recorrente temática oteriana ou risquiana tan estendida na literatura galega prebélica, o apoucado heroe tobiano matina con reiteración no abandono suicida, mais ao final opta pola vida, por marchar a Cuba, aínda que, como ben sabe, esa fuxida no fondo non era máis «que un suicidio sen morte». Mais «Todo é querer. Se a idea de se matar lle deu azos, ¿por que non llos ía dar a arela de vivir, de vivir ben, con sosego e paz [...]?»². Tobío levou dun lado a outro esas follas noveladas e deixounas como esquecidas para que o tempo decidise se os demais as poderiamos ler. Constanza atendeu, con dilixencia filial, a decisión dos anos.

No amigable repartimento temporal, Ínsua e mais eu acordamos chantar as estremas no máis tráxico lindeiro vital de Tobío, na guerra, ou nas continuadas guerras, ás que lle tocou sobrevivir naquela década de terror que asolou Europa, e o mundo, entre 1936 e 1945. Podemos comezar na estancia en Cuba, primeira estación do exilio, coa acordanza da viaxe novelada de Antón á illa grande, onde, en hipótese, Tobío deu por rematado o seu relato.

Denantes fora un ir e vir ao servizo do Goberno da República, en Valencia, en Barcelona, en delegación por Europa, nos países ribeiráns do Mediterráneo, na fronte do Ebro, como tenente de artillaría, como secretario xeral do Ministerio de Defensa en contacto sempre cos galeguistas e «sintindo certa fachenda", cando un día viu «un enorme letreiro do noso partido no balcón dunha casa da Diagonal». Apañando como podía as novas dos amigos vivos, dos valorosos defensores da República pois «[...] non había dúbida, a nosa xente soubera responder con firmidía e azo ás esixencias do momento na loita antifascista»; así o escribiu en As décadas.

${ }^{2}$ A nova vida, p. 142. 
Naquela Barcelona asediada polas bombas, casa cunha moza bastante máis nova, María del Carmen Soler, e comeza o periplo da parella logo da caída de Cataluña. Primeiro París, despois Nova York, logo Cuba ata acougar durante anos en Montevideo. A comezos da década dos sesenta aséntanse en Madrid.

\section{DERIVACIÓNS SOBRE O UNIVERSALISMO}

Antes de enumerar os grandes fitos tobianos do meu período, permítanme un ir e vir no tempo cunha anécdota que, coido, pode expresar bastante ben a concepción do galeguismo tobiano.

A un amigo meu, especialista en arte, propuxéronlle colaborar nunha magna exposición, que ía ter lugar nesa magna dilapidación de recursos que é a Cidade da Cultura ou Gaiás. Esa gran mostra artística acollería preto de 200 obras de pintura, escultura, fotografía etc. Houbo un tempo en que esas obras de arte, algunhas delas magníficas, nos pertencían a todos nós, hoxe a súa propiedade está repartida entre un banco privado e unha fundación que depende dese banco.

O meu amigo acolleu con entusiasmo a suxestión e púxose ao traballo. Furando e furando, chegou a formular unha proposta baixo o rótulo de «A fiestra baldeira». Desbotárona de contado. A exposición cun pouso de vulgaridade e cosmopaletismo rematou titulándose «Galicia universal». Hai quen non comprende que para coñecer o mundo non cómpre pasar por Madrid, que conceptos como identidade e universalidade son complementarios, que universalismo significa aceptación das diversidades políticas nacionais e das súas creacións culturais, e presupón tanto o respecto a estas como a súa defensa ante as ameazas dos imperialismos políticos e culturais. "Nós non queriamos erguer valados, dicía Tobío, senón coidar o noso xardín para que medrasen vizosas as flores da diversidade enriquecedora». Nada máis afastado da visión galeguista de Tobío que esas ideas, que na actualidade gozan de tantos altofalantes, de que o nacionalis- 
mo é un retroceso, un elemento desestabilizador, inviable, antimoderno, que acocha no seu escuro interior perversións autoritarias.

Atinada síntese a de Xulio Ríos:

O universalismo de Tobío é esencialmente político e cultural. Nas súas intervencións nos círculos galeguistas, sempre insistía moito no antiimperialismo, debedor quizais dunha simpatía pola ascendencia marxista, non no sentido doutrinario, senón pola súa forte carga de compromiso social. Afablemente Bóveda, coñecedor das súas teimas, sempre lle andaba coa tranganilla de ¡agora que veña Tobío a darlle aos imperialismos! ${ }^{3}$

Aquel mozo que chega a Berlín (1929-1930), sen pasar por Madrid, e de alá, da capital dunha República que aniñaba o ovo da serpe incapaz de eliminar a palabra «Reich» da súa constitución, tróuxolle, para descubrirllo, a Seoane un álbum de Grosz, a quen aquel non coñecía, e faloulles aos seus amigos de Brecht e «do absurdo e da miseria da guerra, a ridícula fachenda da nova burguesía especuladora, a tesa arrogancia dos militares de monóculo e dentes de cabalo e o aire brutal das camisas pardas».

Retornando ao meu amigo, Carlos Bernárdez formulou a súa proposta en homenaxe á obra teatral de Rafael Dieste, o ideólogo de toda unha xeración artística que procuraba xunguir identidade e universalidade: os Maside, Colmeiro, Seoane etc.; pero tamén para chiscarlle o ollo a aquel rapaz distraído, reverencioso e xovial, amable e escaravelleiro que andaba a apañar palabras e lendas nun feixe de papeis; aquel mozo afable que atopa o xeito de desenlear a tirapuxa teatral.

Recórdanos Tobío en As décadas que escoitou a lectura da obra, aínda inédita, na casa de García-Sabell. Publicouse en 1927. Hai quen quere ver no personaxe

3 Ríos, X. (2001): «O galeguismo universalista de Lois Tobío», en Homenaxes a Lois Tobio, Sada (A Coruña), Ediciós do Castro, p. 68 (Cadernos do Seminario de Sargadelos). 
do intelectual mediador amigo do pintor, que o autor bautizou como Nogueira, trazos do Tobío mozo, aínda que poida ser que o que se aprecien sexan trazos comúns a aquela fornada de mozos que se xuntaron no Seminario de Estudos Galegos ou en xeral a un Solovio ou un Dumbría ${ }^{4}$ en proceso de descuberta dunha cultura nacional oculta.

\section{DOUS TRAZOS DUNHA PERSONALIDADE}

Sempre que matinamos na vida e na actividade pública do viveirense chámannos profundamente a atención dous aspectos. Primeiro, a pesar de que dende 1933 non volveu residir, de forma permanente, en Galiza, o seu pensamento e a súa acción política, cultural, intelectual, sempre estiveron presididas polo «camiño certo» da afirmación dunha nación negada e urxida da permanente necesidade de afirmación.

A identificación co destino do seu país é a cerna do pensamento tobiano, que ten a súa xénese nos seus anos mozos marcados a ferro pola traxedia e a nova Europa que nacía dos rescaldos da Gran Guerra, aparentemente sufocados en Versalles. O seu galeguismo xurdía da lúcida percepción de que non todas as nacións europeas puideron abrollar despois da desfeita dos imperios decimonónicos e que ese feito e mais o forzado deseño do mapa europeo, nomeadamente no caso alemán, achegaban altas doses de inestabilidade á explosiva realidade condicionada polas vellas pulsións imperiais e a dexeneración moral e política representadas polos fascismos varios.

Coñeceu de primeira man estas tensións cando no inverno de $1929^{5}$ chegou ao Berlín que anunciaba o ascenso nazi e alí conviviu, e sobre todo confrontouse, con Risco, como este último deixou recollido no seu Mitteleuropa. Por iso

\footnotetext{
4 Personaxes de Otero Pedrayo en Arredor de si (1930) e Devalar (1935), respectivamente.

5 Maseda, F. (2010): Lois Tobio: vida e obra dun humanista galego e un galeguista universal. Tese de doutoramento (inédita).
} 
Tobío consideraba que as pequenas nacións poderían ser comprendidas dende os postulados do marxismo e de formulacións políticas concretas por el inspiradas que viñan de admitir a independencia de Finlandia, Estonia, Letonia, Lituania, Polonia..., pero non dende os preceptos reaccionarios cos que comungaba Risco. Por certo, que ao mellor se pode tomar como mostra de tolerancia entre os que coinciden parcialmente pero manteñen profundas diverxencias que fose na revista dirixida polo ourensán onde Tobío deixou escrito: «Esto permítenos falar, [...]. Non que, obxectivamente, eisista un esprito do pobo, un "volkgeist", máis ou menos místico. $\mathrm{O}$ esprito d'un pobo, a i-alma d-unha comunidade natural, eisiste somente coma "representación" na conciencia dos individos e n'iste senso subxectivo pode ser sentido e amado; en verdade, somente se poden sentir e amar as "representacións" ${ }^{6}$.

Tobío era un fillo dos 14 puntos do presidente Wilson, formado no respecto ao dereito internacional de autodeterminación e soberanía das nacións e na procura do punto de encontro entre a esquerda social, a democracia e a libre determinación das nacións. Como Castelao, Tobío nunca se reclamou do marxismo, mais consideraba esta ideoloxía como próxima, non só como un método de análise senón tamén como proxecto de xustiza social. «O marxismo é un dos sistemas mais pretos da realidade [....]. Quen non esteña ben penetrado da lóxica real do marxismo non poderá enxergal-o, nin poderá enxergar toda a forza de verdade que n-il latexa», escribía en Nós en $1931^{7}$. Nese achegamento exerceu grande influencia o seu mestre en Berlín, Herman Heller, socialdemócrata marxista, para quen o elemento esencial do Estado é a cidadanía, que atopa no desenvolvemento da constitución o recoñecemento dos dereitos civís e da igualdade social, só alcanzables pola vía da democracia e da acumulación de reformas políticas e sociais ${ }^{8}$.

\footnotetext{
6 «Refreisións encol do momento aitual da Galicia», Nós, 15 de novembro de 1931, núm. 95.

7 Ibídem.

8 Heller tivo que fuxir da Alemaña nazi. Refuxiouse no Madrid republicano e faleceu novo, en 1933. Tobío traduciu ao español a súa Teoría del Estado, cuxa tradución segue tendo plena vixencia na actualidade.
} 
Era o seu un galeguismo xerminado nos desastres da gran guerra e nas arelas de xustiza social que estourara coa revolución rusa. Tocoulle ver como aquel mundo ficaba varrido polo rearme imperial do sistema de bloques e a imposición dos autoritarismos imperiais, dentro e fóra dos propios imperios.

Seméllame significativo o aparente detalliño que relata a súa filla, Constanza, no libriño co que se lle agasallou por mor do seu 95 aniversario. Na casa, a súa muller, Melu, sempre lle chamou Lois. Coido que nesta identificación hai moito máis que unha simple anécdota. Nesta ausencia-presenza, salvando as distancias temporais e ideolóxicas, Tobío lémbrame ao padre Sarmiento, quen, vivindo en Galicia aínda menos tempo que Tobío, lle dedicou á súa cultura ímprobos esforzos.

O segundo aspecto que me chama a atención é o seu sentido do necesario, da oportunidade, do matinar no futuro, de ollar para adiante, de achandar camiños; en definitiva, de estar aberto á innovación e á vangarda. Así era Tobío tanto no eido persoal coma no ideolóxico ou no político. En todas as grandes iniciativas políticas do nacionalismo da primeira metade do século XX aparece Tobío, xa se referiu a iso o amigo Ínsua. Tobío non é personaxe que procure o foco, senón o fogueiro que subministra ideas á locomotora, o mediador que sabe da importancia do diálogo, do contraste de pareceres, mais tamén da necesidade de achegar posicións entre os que participan do mesmo proxecto.

Temos aí ao Tobío de vangarda, non o vangardista, senón o que roza o camiño, o «camiño xusto», diría el, os múltiples e variados camiños polos que se debe expresar a vitalidade creadora da nación cidadá en construción permanente. Non é un destemido botado para diante pero tampouco un simple compañeiro de viaxe, senón un traballador consciente dos moitos eidos nos que labrar dende a conciencia colectiva. 


\section{TRES FITOS DO SEU ACTIVISMO GALEGUISTA}

Sobre o seu activismo galeguista digamos que Tobío está ao coidado da máquina en tres dos grandes fitos do galeguismo político de posguerra no exilio: a formación do Consello de Galiza, o Congreso da Emigración do ano 56 e a edición dos dous primeiros volumes do inacabado proxecto de edición da «Grande e General Historia» en denominación do seu gran amigo Otero Pedrayo.

\subsection{O Consello de Galiza}

Camiño de Bos Aires, Castelao detívose en Montevideo o 17 de xullo de 1940. Tobío estábao agardando, xunto a moita outra xente. Naqueles anos o rianxeiro regresou en varias ocasións a Montevideo. Mais en maio de 1944 fíxoo para falar en privado con Tobío dun proxecto ao que lle andaba a dar voltas e que ao final se denominaría Consello de Galiza. Esta fora a denominación que escolleran Carballo Calero e mais Tobío para o goberno galego no Anteproxecto de Estatuto que fixeran para o Seminario de Estudos Galegos.

Tobío fornece dalgúns datos concretos a Valentín Paz-Andrade cando o vigués andaba a traballar no seu Castelao na luz e na sombra nunha carta asinada en Madrid o 30 de maio de 1981:

En maio de 1944 foi Castelao a Montevideo e quixo falar conmigo verbo do instalación do Consello de Galicia. Eu dinlle algunhas ideias sobre a forma xurídica que se lle podería dar. Pideume que lle mandara por escrito esas suxerencias. Fíxeno. A eso se refire a carta que che adxunto fotocopia. O Consello constituírase logo en Bos Aires. En Montevideo nomeouse un representante que seique foi Canabal (non estou seguro). O Consello, como sabes, estaba integrado polos diputados galegos no eisilio. En Montevideo non había ningún?.

9 Carta de Tobío a Paz-Andrade, 30/05/1981. Aínda que despois rectifica Tobío á man: «Si estaba Somoza». Arquivo Tobío. 
Aos poucos días de visitalo en Montevideo, Castelao envíalle unha carta ${ }^{10}$ na que, ademais de lle achegar uns documentos xa vellos ${ }^{11}$ pero que podían ser de interese para Tobío, agradece as súas opinións e quéixase dos que só fan confundilo:

Cheguei preñado de canto ti me dixeches. Certamente eu necesito de tí, porque xa non teño tempo de improvisar o camiño que nos leve ao interior. Tampouco teño a miña beira quen me axude nos traballos, pero abondan e sobran os que me enterrumpen e confunden. Faime o favor de mandarme os esquemas que che pedín. Eso será ouro para $\min$. Non te esquezas ${ }^{12}$.

Tobío sempre lamentou que as cartas e documentos referidos ao proceso de constitución do Consello de Galiza ficasen en Montevideo, por consideralos perigosos, cando se trasladou a Madrid. Deixounos ao coidado pero os avatares da vida levaron ao seu extravío. En calquera caso, consideraba que o substancial do que el aconsellou era coñecido: construír un soporte legal da lexitimidade política do Consello sobre o concepto dun órgano fideicomisario da vontade da autonomía do pobo galego, depositada nos seus deputados electos en febreiro de 1936. Tobío foi pois o inspirador xurídico do proxecto que se presentou en público, no Ateneo de Montevideo, o 30 de xuño de 1945. Di Tobío: «Castelao foi nomeado presidente e, como tal, actuará en representación de Galicia, xunto cos vascos e cataláns, en Galeuzca, restaurada no exilio, máis adiante entrará co mesmo carácter no goberno da República Española que se constituíu en París presidido por Giral» ${ }^{13}$.

\footnotetext{
${ }^{10}$ Carta de Castelao a Tobío, 12 de maio de 1944. Arquivo Tobío.

11 Trátase, entre outros, dun artigo do 6 de novembro de 1938 do prestixioso xornalista político británico Herbert Sidebotham, coñecido como «Scrutator» polos lectores do Sunday Times, no que se refire á política de Chamberlain para Italia e España. O xornalista británico, xa falecido na altura da misiva de Castelao, afirma categórico no seu artigo: «Ninguén dubida que a única solución que traerá a paz permanente a España é unha solución federal. Hai catro Españas: País Basco, Galicia, Cataluña e o resto».

${ }^{12}$ Carta de Castelao a Tobío, 12 de maio de 1944. Arquivo Tobío.

${ }^{13}$ As décadas..., p. 535.
} 
Castelao sempre devecera por ter a Tobío á súa beira. Conta Carlos Casares, na súa colaboración no libro Homenaxes a Lois Tobio, que entre os retallos da memoria das súas últimas conversas con Piñeiro lembraba que este lle contara que na altura de 1937 se barallou a posibilidade de nomear a Castelao embaixador da República en Bos Aires. Co asunto avanzado, o rianxeiro reclamou unha persoa de confianza para que o acompañase e que fose Lois Tobío. Seica as autoridades do Ministerio de Estado consideraban imprescindible a presenza de Tobío en Sofía, polo que lle denegaron a petición. Castelao pensou entón en Carballo Calero. Mais daquela as cousas pintaban feas para a República, produciuse unha crise que rematou coa substitución á fronte do Goberno de Largo Caballero por Negrín. Giral asumiu entón o Ministerio de Estado e o nomeamento prometido ficou en suspenso. Castelao sempre pensou que fora cousa de Giral, que, na reviravolta do camiño, estará á fronte do Goberno no exilio cando Castelao sexa ministro grazas, entre outras cousas, á lexitimidade que achegaba presidir o Consello de Galiza despois de que a autonomía acadase o seu pleno recoñecemento nas Cortes Republicanas reunidas en México uns meses antes. Castelao sería fiel a Giral.

$\mathrm{O}$ final da guerra, o novo panorama internacional de bloques, a morte de Castelao, a continuidade do franquismo, a división entre o galeguismo do interior e o do exilio e o falecemento da maioría dos deputados fideicomisarios arrastraron o Consello de Galiza á perda de iniciativa e ao esmorecemento paulatino. É ben certo que a iso tamén axudou que o Goberno autónomo galego nunca se chegase a constituír como tal, a diferenza do vasco e do catalán, mais non explica na súa totalidade o gran desatino que foi permitir que secase a fonte de lexitimidade democrática e autonomista que representaba o Consello de Galiza.

A autonomía galega pagou un alto prezo por tal desleixo. No momento da reforma do franquismo e do restablecemento das autonomías históricas, puxéronse á fronte dos órganos preautonómicos persoeiros procedentes do réxime ditatorial, mesmo fondamente comprometidos coa represión franquista e inmersos na operación de adecuación das elites da ditadura aos novos tempos anunciados pola morte de Franco. Non só non se respectou, nin sequera se 
reclamou, a continuidade histórica da lexitimidade democrática e republicana representada polo Consello de Galiza, senón que nin se considerou a posibilidade de que Antón Alonso Ríos asumise ese papel simbólico e momentáneo, como fixeron Leizaola ou Tarradellas no caso vasco ou catalán, respectivamente. A liña da continuidade democrática representada por Aguirre, Irla e Castelao, interrompida pola sublevación militar, ficou esbarroada no caso galego e un personaxe como Rosón converteuse en presidente da Xunta preautonómica.

E non só iso, senón que a ninguén se lle ocorreu nin sequera solicitar a colaboración de Tobío, el levaba máis de vinte anos residindo en Madrid, na redacción do actual Estatuto ou simplemente demandar a súa opinión.

Entre outros moitos factores, coido que este corte na lexitimidade democrática pode explicar, en parte, a despreocupación popular nos momentos iniciais da autonomía, fóra do momento da aldraxe, e mesmo a posterior e actual languidez das institucións autonómicas. Mais tamén a certa orfandade en que medrou o renovado e xuvenil nacionalismo galego dos primeiros anos setenta, que impediu que este non só non asumise un papel comprometido no proceso autonomista senón que, pola contra, na procura da súa propia forte identidade, se desmarcase do proceso e se enfrontase a el, cometendo un erro de perspectiva histórico que o sumiu nunha fochanca de marxinalidade da que tardou moito tempo en ser capaz de emerxer. Quen nos dera daquela poder chegar aos consellos de quen sabía e de quen, como di Francisco Fernández del Riego, «Nunca lles negou consello a quenes o necesitabamos» ${ }^{14}$.

\subsection{O Congreso da Emigración}

Seis anos despois da morte de Castelao, o Consello de Galiza, presidido por Antón Alonso Ríos, acordou convocar o I Congreso da Emigración Galega coa

\footnotetext{
${ }^{14}$ Fernández del Riego, F. (2001): «Os ensinos do vello amigo», en Homenaxes a Lois Tobío, Sada (A Coruña), Ediciós do Castro, p. 38. (Cadernos do Seminario de Sargadelos).
} 
evidente intención de reagrupamento e coordinación dun proxecto galeguista debilitado pola morte do rianxeiro, a continuidade do franquismo e a escasa perspectiva da súa data de caducidade.

A decisión de realizar o congreso que reunise os emigrantes en América tomouse na xuntanza extraordinaria do Consello de Galiza do 2 de xaneiro de 1956. Acordouse facelo en Bos Aires entre o 24 e o 31 de xullo de 1956, datas escollidas para conmemorar o Centenario do Banquete de Conxo. Nomeouse unha comisión organizadora integrada basicamente por representantes da comunidade bonaerense, reunidos arredor a figura de Manuel Puente, mais que non recollía outras sensibilidades, ou cando menos non coa intensidade da que eran merecentes, como no caso da Federación de Sociedades Galegas, e deixaba fóra outras, como a Asociación Galega de Universitarios, Escritores e Artistas (AGUEA), que se expresaban a través da revista Galicia Emigrante que dirixía Luís Seoane.

Coñécese moi ben o seu desenvolvemento pois a Editorial Nós de Bos Aires editou as Actas do Congreso. Realmente non son unhas actas, senón unha múltiple e variada documentación sobre os preparativos e o desenvolvemento da reunión que se publicarán tres anos despois da súa realización ${ }^{15}$.

En 2006, coincidindo co cincuenta aniversario da súa celebración, o Arquivo da Emigración do Consello da Cultura Galega publicou unha edición facsimilar das Actas ${ }^{16}$. No estudo previo, Marcelino Fernández Santiago valora:

A pesar do escaso tempo desde a convocatoria do Congreso até o seu comezo, rexístrase unha importante participación, xa que asisten un total de 134 delegados e están representadas 60 sociedades. A case totalidade das sociedades participantes son entidades dos países do Río da Prata, cunha moita menor participación e relevancia das sociedades

\footnotetext{
${ }^{15}$ Editorial Nós, Bos Aires, 1959. A edición estivo ao coidado de Súarez Picallo, Francisco Regueira, Rodolfo Prada e Manuel Porrúa.

${ }^{16}$ Pódese consultar en http://consellodacultura.gal/publicacion.php?id=162.
} 
doutros ámbitos xeográficos pois, do total de entidades adheridas, 45 son institucións galegas con sede en Arxentina e Uruguai.

Tobío é reclamado de novo para facer de locomotora para que o tren pite e ande. Foi o encargado de elaborar o «Manifesto», o «Temario» e mais o «Regulamento», mediar nos momentos de tensión e organizar o desenvolvemento dos actos.

No «Manifesto», o de Viveiro refírese á decisión do Consello de Galiza de organizar o Congreso en coincidencia co Centenario do Banquete de Conxo, evidenciando así unha continuidade no proxecto ideolóxico político galeguista:

Por iso decidimos convocar este Congreso da Emigración Galega n-este ano de 1956. Coincidirá co centenario do «Banquete de Conxo» feito de fondo siñificado na historia do noso Rexurdimento. Naquel sonado banquete, estudantes e obreiros, irmanáronse afervoadamente baixo a dobre inspiración do amor á democracia e do amor a Galiza. As verbas ardidas do bardo Pondal e do poeta Aurelio Aguirre que resoaron coma voces de profecía baixo a ramallada da vella carballeira e seguirán resoando arreo ao longo dos anos, serían recolleitas por xeración tras xeración de galegos, inspirando os seus esforzos a prol do avance e felicidade e liberdade da sua Terra. I-é axeitado poñer un Congreso da Emigración Galega baixo o siño do Banquete de Conxo porque no esprito dos que n-iste participaron bulían os ideaes que deben inspirar aos emigrantes galegos: a irmandade antre a mente e o brazo, antre o inteleitual e o traballador manual, o senso de igualdade humán, o principio de liberdade democrática, o amor aitivo á Terra galega e a arela de vela ergueita e ceibe.

O «Manifesto» é unha chamada ás comunidades da emigración porque esta «ten chegado xa a un intre, na súa evolución, en que precisa tomar conciencia de sí mesma e autodeterminar os seus rumbos». A convocatoria parte coa esperanza de que «representará un importante paso na empresa cada ves máis urxente e ineludibre, de estroituración da Galicia Emigrada». 
Na súa análise da emigración galega, Tobío considera que esta:

Insértase ela dondamente, sin brusquedade nin violencia na comunidade que a recebe («o galego non foi a turbare ningunha inocencia» dí, maxistralmente, Otero Pedrayo) como un regato que deitara mainiñamente as súas augas. E logo axéitase de contado á nova vida, ao novo meio, orixinando un mínimo de friccións, establecendo fíos de cordialidade, irmandade e convivencia sinceira e fonda coa xente do país. I-elo -i-eiqui ven o interesante e cáseque o miragroso- sen desfacer e liquidar a sua condizón galega ${ }^{17}$.

Tobío argallou o desenvolvemento do congreso en tres grandes palestras. $\mathrm{Na}$ primeira afrontouse o estudo do pasado migratorio dende as orixes nas migracións andoriñas a Castela e Andalucía ata a máis duradeira emigración americana do século XIX, a análise dos centros de atracción migratoria e as razóns para o funcionamento destes, así como as características psicolóxicas e sociolóxicas do emigrante e as súas creacións mutualistas, culturais e recreativas e empresariais no pasado. Na segunda palestra analizouse o presente, naquela altura, da migración galega e as súas características xerais nas máis importantes zonas de concentración.

O máis denso dos paneis argallados foi o terceiro, que atendía ao futuro da emigración e amosaba tanto o espírito de ollar «máis alá», propio de Tobío, como o seu xeito pragmático de entender a acción política. A densidade temática fixo que esta terceira palestra tivese catro desenvolvementos parciais.

Para esmiuzar o problema do colectivo emigrado comeza por preguntar se convén promover ou restrinxir a emigración, inquire sobre vantaxes e prexuízos. Sobre a forma en que se organiza, cuestiona se os estados e as entidades de migrantes deben intervir na súa orientación ou ben se non se debe coutar a libre determinación individual.

${ }^{17}$ Primeiro Congreso da Emigración Galega. Documentación. Crónicas, Bos Aires, Editorial Nós, 1956, p. 13. 
Así mesmo abriu o debate sobre as mínimas condicións de saúde, capacitación e alfabetización; desenvolvendo en maior detalle o rol das sociedades galegas tanto na asistencia ao emigrado a través de bolsas de traballo, axudas económicas, asistencia médica gratuíta, axudas para os repatriados etc., como na capacitación do emigrado a través de escolas, centros de formación profesional e artística. Non deixa Tobío de presentar a consideración aspectos máis sutís como o senso ético do emigrante e a súa tendencia ao «afroxamento da sensibilidade moral» e «a necesidade de conservar os "standards" éticos».

No segundo apartado deste terceiro panel Tobío propón a reflexión sobre as sociedades mutualistas como máxima creación da emigración e expresión do cooperativismo tradicional e o estudo das posibilidades de estender a súa acción á sanidade, beneficencia e cultura, así como as posibilidades de coordinación entre as sociedades mutualistas dentro de cada país e coas doutros países. Finalmente suxire abordar o «rol espritoal» das mutualidades fomentando a relación entre Galiza e as nacións americanas co estudo polo miúdo do influxo de América en Galiza, e á inversa, a través dos emigrados.

Non se lle escapa orientar os debates cara á vida económica e facelo con ese profundo sentido da xustiza social sempre presente no pensamento tobiano e propón directamente cuestións como: «Comenencia de adicarse a aitividades productoras: vantaxes para o país e para o emigrante. Os perigos das aitividades económicas parasitarias (especulación, usura), e necesidade de manter ao noso emigrado arredado d'elas»; para deseguido presentar:

A acción dos galegos emigrados cara á vida económica galega. Posibilidades de aituar n'ela. Dificultades, e maneiras de vencelas. Axuda do emigrado á economía familiar galega, valor d'esta axuda e efectos na aitividade económica xeral. Ingreso en Galicia de capitales emigrados, Empresas fundadas por emigrados que volven ${ }^{18}$.

${ }^{18}$ Primeiro Congreso da Emigración Galega. Documentación. Crónicas. Editorial Nós, Bos Aires, 1956, p. 18. 
O derradeiro apartado deste terceiro e complexo panel sobre o futuro está dedicado á cultura. Partindo das accións concretas, por exemplo a axuda a empresas culturais da Terra e a urxencia de acrecentala (en referencia indubidable á editorial Galaxia pero non só), o apoio ás grandes empresas culturais que explicita: a «Historia de Galiza», aclara Tobío, en camiño de cumprirse (descoñecía que o proxecto se atrasaría en demasía e sería el mesmo quen tería que arrimar de novo o ombreiro para botalo adiante), ou o Gran Dicionario Galego, proposto no relatorio do interior. Aspectos aos que nos referiremos máis adiante. Nesa visión ampla da cultura que ten Tobío, non reducida á literatura, presenta a necesidade de fomentar o teatro, as artes plásticas, a música e a difusión da cultura a través de diarios, revistas, editoriais e da radio ${ }^{19}$. Finalmente postula o debate sobre a lingua galega e a "Obriga de gardala e cultivala como herdo, o máis valioso, da nosa cultura. Aititude da emigración galega cara ás medidas de persecución -aberta ou disimulada- da nosa lingua. Necesidade de crear crases elementaes e crases superiores de lingoa e literatura galega na terra e na América». Remata propoñendo a reflexión sobre as achegas da emigración ás culturas nacionais dos países americanos e os xeitos de realizalas.

No regulamento Tobío argallou comisións para os tres grandes paneis; o terceiro ficou dividido en tantas comisións como apartados temos sinalado. Deseñou o acto de apertura e clausura e os distintos pormenores dun congreso

\footnotetext{
${ }^{19}$ En 1950, concretamente o 3 de setembro, un fato de galeguistas e republicanos, encabezado polo exdeputado de Izquierda Republicana e curmán de Castelao, Alfredo Somoza, entre os que podemos sinalar a Xesús Canabal, Manuel Meilán, Antón Crestar, Pedro Couceiro, Emilio Pita, Manuel Leiras e Lois Tobío, deciden iniciar unha audición radiofónica en galego. A lexislación uruguaia permitía emitir en calquera idioma e esa oportunidade aproveitárona os galeguistas e exiliados para facer chegar a súa mensaxe a todo o territorio uruguaio, parte do arxentino e ao sur de Brasil. Era a primeira vez que se emitía un programa radiofónico integramente na nosa lingua. A súa estrutura, de media hora de duración, mantívose durante moito tempo e hoxe é moi similar: abríase cun tema musical, ao que seguía un editorial e logo comentarios sobre lingua, historia, xeografía etc. Durante décadas a emisión dominical foi a escola de lingua e cultura de miles de emigrantes galegos e galegas, e chegou a ter unha grande audiencia. Na primeira década, Tobío, Couceiro ou Meilán eran os encargados de elaborar os editoriais, o que non impedía que realizasen tamén outras colaboracións en Sempre en Galiza, que así se chamaba, e chama, a emisión. Tobío sempre innovando.
} 
destas características. Resolveu, con habilidades varias, a participación nel, dándolle a cada sociedade un voto, asistisen as persoas que asistisen; outorgándolles voz e voto a editoriais, revistas, periódicos e audicións radiofónicas e tamén a todas as persoas que polo seu labor destacado fosen convidadas pola comisión organizadora.

Aquí terá que lidar, con éxito, en momentos de tensión como o xerado por non convidar a participar na organización a AGUEA, «chata que mesmo hoxe non me dou explicado", comenta Tobío en As décadas. Tivo pois que botar man dos seus dotes diplomáticos para evitar o boicot, por parte das persoas agrupadas arredor de Galicia Emigrante, a revista que dirixía Luís Seoane, e conseguir que, ao remate do congreso, a casa común ficase reforzada. Cóntao así Tobío tamén en As décadas (p. 592):

Cando chegamos a Buenos Aires os delegados de fóra para participar no Congreso, fomos invitados polos de AGUEA a un xantar ao que asistimos gustosos pero que veu ser unha «encerrona» pois, ao remate de el, Blanco Amor, coaquela súa verba engaioladora, quixo convencernos de que debiamos boicotear o Congreso. Pero xa era tarde para tomar unha tal decisión, anque estivese xustificada. Prometimos, porén, unanimemente, intervir para que se remediara aquel erro e así o faremos, conseguindo que a AGUEA fose, ao cabo, invitada a participar como era xusto. E na sesión solemne en que se aprobaron as ponencias, o meu vello amigo Antonio Baltar pasou a formar parte da mesa, en representación da AGUEA, entre os afervoados aplausos de todos.

Será tamén Tobío quen xestione a colaboración de Leopoldo Nóvoa, residente na altura en Montevideo, no deseño do programa de man e, posteriormente, tamén logrará implicalo na edición da Historia de Galiza que dirixía Otero Pedrayo.

Tobío interveu o día anterior á clausura, nun dos actos culturais que arrouparon o congreso e que tivo lugar na sede do Centro Galego de Bos Aires no núm. 21999 da rúa Belgrano, á beira de Emilio González López, residente en 
Nova York, e de Xerardo Álvarez Gallego, exiliado na Habana. Faino tamén no acto de clausura, o 28 de xullo, como autor do «Regulamento», do «Manifesto» e do «Temario». O labor de Tobío reconéceo con intensidade o presidente da comisión organizadora, don Manuel Puente, quen no resumo publicado ${ }^{20}$ do seu discurso na sesión de clausura di:

Mais teño a obriga de siñalar e de eisaltar a quen foi autor e alicerce que posibilitou o éisito. Os organizadores tivemos senso de responsabilidade e, naturalmente, acudimos a un irmán sabido para que nos fixera unha laboura que nós, homes emigrantes sen preparación nin capacidade inteleitual, non podiamos facer; a saber: a estroituración literaria, temática e regulamentaria do Congreso. E acodimos a un irmán que vive en Montevideo, quen, pola súa sinxeleza, -belida fror espritoal-, pola súa caridosa comprensión da maneira de ser, do sentir e do pensar dos irmáns emigrados, e ademais polo seu afervoado patriotismo galego, ceibe de infruencias alleeiras, úneca i escrusivamente comprometido coa Terra sagra, coa Galicia nai...; ise irmán a quen nós e a patria lle estaremos por sempre agradescidos, é un home que nos honra eiquí coa sua compaña; don Lois Tobío.

Mais non todos os que presentaron comunicacións ao citado congreso eran emigrantes ou estaban no exilio, tamén participaron os do «exilio interior», comezando por Otero Pedrayo, que envía un breve relatorio manuscrito, reproducido en forma facsimilar na documentación do congreso baixo o encabezamento «Mensaxe do esgrevio dianteiro da cultura galega: Don Ramón Otero Pedrayo». Tobío destaca en As décadas a importancia deste breve e emocionante escrito de Otero.

Don Ramón asina tamén -xunto con Ramón Cabanillas, Xoán Rof Carballo, Domingo García-Sabell, Ricardo Carballo Calero, Celestino Fernández de la Vega, Francisco Fernández del Riego, Xaime Illa Couto e Ramón Piñeiro- outro

${ }^{20}$ Primeiro Congreso da Emigración Galega. Documentación. Crónicas, Bos Aires, Editorial Nós, 1956, p. 38. 
relatorio, presentado na comisión cuarta do terceiro panel: «A emigración galega e-a cultura», no que se nota a man de Piñeiro e que debe ser unha das primeiras formulacións escritas do que se deu en denominar «piñeirismo» ou «culturalismo», que se plasmaría na célebre reunión de 1958 na que o grupo de Galaxia entregou a Perfecto López, do grupo de Bos Aires, un extenso informe ${ }^{21}$ no que se fixaban as posicións do chamado «galeguismo do interior» e que provocaría o posterior afastamento entre os dous núcleos do galeguismo, aínda que esta distancia xa viña da década anterior, dos momentos previos ao nomeamento de Castelao como ministro no Goberno da República.

O relatorio remitido dende Galiza céntrase na defensa do idioma como empresa común dos galegos e fai dúas propostas: a elaboración do Gran Dicionario Galego e a creación dun Padroado da Cultura Galega. A primeira sería un profundo labor de estudo da lingua: «Para procedéremos metodicamente na posta en marcha distes estudos, temos que comezar, necesariamente, pol-a publicación escrupulosa de todol-os materiás lexicográficos que van integrar o futuro gran Diccionario»22.

Estes serían a publicación de documentos medievais esquecidos nos arquivos, de textos medievais con comentarios críticos e doutros inéditos, de vocabularios (Sobreira, Sarmiento, Cornide, Pintos, Leiras Pulpeiro e nomeadamente o de Eladio Rodríguez) e, finalmente, a recollida da lingua viva en monografías lexicográficas. Para afrontar estes labores é para o que propoñen a creación do Padroado: «Para artellar a adecuación entre os medios económicos e mail-os medios técnicos que se precisan, sen que a adecuación perda continuidade» ${ }^{23}$.

Dende o punto de vista histórico e ideolóxico teñen máis interese as dúas primeiras epígrafes denominadas «Siñificado da cultura» e «Idioma e cultura»,

\footnotetext{
${ }^{21}$ Publicado, en parte, no núm. 111 de Grial: «Ramón Piñeiro. Da miña acordanza», Vigo, tomo XXIX, 1991.

22 Primeiro Congreso da Emigración Galega. Documentación. Crónicas, p. 176.

${ }^{23}$ Ibídem.
} 
respectivamente, nas que son constantes as referencias á cativeza de Galiza no marco europeo, ao seu carácter de «pobo» xa que se expresa como unha cultura "peculiar», isto é, unha "unidade espiritoal que ten a súa máis representativa expresión no idioma.

Ao respecto da división entre os galeguistas do interior e os de Bos Aires, ou se se quere, entre culturalistas e políticos, Tobío mantén unha posición intermedia, quizais derivada da súa experiencia política e diplomática. Dicíanos: «Ben, non hai que facer unha división tan radical e esquemática, porque entre os culturalistas había individuos que tiñan senso político e entre os políticos había moitos individuos que traballaban na orde cultural. Todos discutiamos, pero por riba estaba o mesmo sentido da galeguidade, que era o que nos unía a todos e que se impuña a todo». Para logo engadir:

Non se durmiu ao PG: deixar que non actúe dunha maneira activa, puxante, nun determinado momento, non quere dicir que iso supoña unha perda de espírito. Aqueles que parecían soamente políticos eran tamén culturalistas, e viceversa. Eu falaba con todos eles, uns e outros tiñan o mesmo obxectivo. O que pasa é que había quen lle daba máis importancia, nun momento, a un aspecto, e outros que lle concedían máis importancia a outro, pero todos tiñan os dous aspectos presentes. Era nas tácticas onde podían discrepar, pero só lixeiramente. Máis política ou menos política, máis cultura ou menos cultura, non deixaban os políticos de facer cultura nin os culturalistas de facer política ${ }^{24}$.

\subsection{Tobío editor}

Ao pouco de que o Consello de Galiza convocase o I Congreso da Emigración e cando Tobío estaba inmerso nos labores preparatorios, Rodolfo Prada, nunha carta datada o 23 de febreiro de 1956, demanda de Tobío unha primeira

${ }^{24}$ Pellitero, L. / R. Pascual / C. Méixome: «Lois Tobío. Crónica viva dun século», Tempos Novos $(18 / 03 / 01)$. 
colaboración nun proxecto editorial: «Agora teño o gosto de cumprir outro encárrego para vosté. Trátase do seguinte: da grandeira obra, que patrioticamente financia noso esgrevio amigo Don Manuel Puente, da Historia de Galicia». A seguir coméntalle que naquela altura recibiran os orixinais dos dous primeiros tomos e que «xa istán sendo imprensados. Don Manuel contratou o traballo ca imprensa López de ista cibdá (a mesma que fixo o libro "As cruces de Pedra na Galiza” de Castelao), en 400 e pico mil pesos. Amáis delo, os grabados custarán uns 150 mil pesos. Isto lle dará ideia da importanza da obra».

Infórmao de que a edición está a cargo de «Luís Seoane axudado por mín» e preséntalle a demanda de colaboración:

Agora ben, témolo probrema da correición das probas, non pola correición [...], senón pola necesidade de unificar a ortografía dos varios traballos de diferentes autores. Elo comporta unha responsabilidade que somentes pode ser asumida por persoa autorizada por unha outa preparación intelectual e amplo conocemento da nosa lingua, pois vai toda a obra en idioma galego. Con Otero Pedrayo tense acordado que se faga a primeira corrección, -e conseguinte unificación ortográfica e linguística-, eiquí, enviándose a éle a derradeira proba para sere revisada e conformada alá.

Agora ben, Seoane e máis eu entendemos que vosté é a persoa máis calificada nas terras do Plata para laboura tan importante. Don Manuel atopou perfeita a eleición e fíxome o encarrego de lle escribir propoñéndolle isa colaborazón e pregándolle queira aceitala, a base, naturalmente, de lle compensar cos honorarios que correspondan, xa que o traballo será fadigoso e lle demanadará tempo que vosté perdería de adicar a labouras periodísticas ou editoriaes que lle rinden beneficios.

A imprensa xa entregou as probas dos primeiros traballos: o Prólogo e a Descripción Xeográfica de Galicia, ambos de Otero.

A carta de Prada remata cunha posdata: «Eu permítome apelar afervoadamente ao seu patriotismo galego, para que faga o sagrifizo de aceitar o encárrego». 
Lois Tobío, sempre disposto a realizar os imprescindibles traballos de intendencia, asumiu primeiro o labor de transcribir e unificar a ortografía, tarefa nada doada xa que como el mesmo lembra: «Algúns dos traballos estaban escritos a man con letra a veces non moi clara, a comezar pola de Otero, e a ortografía era dabondo diferente duns a outros ${ }^{25}$. Aceptada a petición inicial, os problemas xurdidos, tanto coa imprenta como por outros motivos, fixeron que a publicación se fose adiando. Cinco anos despois da carta de Prada aínda non se publicara o primeiro tomo nin tiña moitos visos de facerse realidade. Este atraso e mesmo o perigo de que a edición non se realizase foi o que levou a Tobío a asumir todo o labor editorial, correspondendo deste xeito á petición que lle fixeran na súa casa de Montevideo Manuel Puente, Rodolfo Prada e Carlos Abraira. No complexo do labor editorial redunda M. Puente:

[...] doume perfecta conta do enorme traballo que siñificou para vostede por en orden os orixinás e todo o demais de clichés etcétera; o desorden nos orixinás non foi por falta das nosas recomendacións, que chegamos a pedirlle se puxeran dacordo na unificación do idioma etcétera ${ }^{26}$.

No seu arquivo persoal, Lois Tobío conservou unha serie de documentación (correspondencia, facturas, deseños etc.) referida á edición dos dous primeiros volumes, entre a que cómpre salientar unha boa morea de cartas que nos achegan ás múltiples dificultades, nomeadamente económicas, que tiveron que superar todos os colaboradores, fosen estes autores, correctores, deseñadores ou fotógrafos, só superadas con esforzo e dedicación. Sirvan estas liñas para recoñecer o seu labor.

A comezos do ano 1961 Tobío asumirá o labor de coidar da impresión dos traballos que estaban realizados. Manuel Puente comunícalle ${ }^{27}$, tamén lle envía copia da carta que lle remitira uns días antes a Otero Pedrayo, que:

\footnotetext{
25 Tobío, L.: As décadas..., p. 633.

${ }^{26}$ Carta de M. Puente a Tobío $(10 / 01 / 62)$.

${ }^{27}$ Carta de M. Puente a Tobío (12/01/61).
} 
[...] baixo a miña responsabilidade económica vostede está autorizado por min para resolver todo o necesario para a impresión da Historia de Galicia -confírmolle a vostede o que lle escribín a Don Ramón, e convimos personalmente na súa casa- esto é que lle ordene a Don Ramón ou conveña cos colaboradores desiñados ou outros, o que vostede considere necesario para a termiñación da obra.

A confianza de Puente en Tobío é absoluta, na mesma misiva engade:

En canto ós materiaes no seu poder -colaboracións, debuxos e mapas- proceda tamén con toda libertade -o que non lle guste desbóteo- e co que sirva proceda a facer imprimir os primeiros tomos contratando como mellor lle pareza, é avisándome solamente para abonar as cuotas que vostede conveña.

Como comentamos, coa carta anterior M. Puente mándalle a Tobío copia da que lle enviara a Otero. Nesta Puente explícalle ao director da publicación as razóns do atraso da impresión:

Estou seguro que vostede estará estrañado da falta das miñas noticias, en tanto tempo, pero pódolle asegurar que naides como eu estaba sofrendo por non poder escribirlle algo satisfactorio encol da empresa que me comprometín coa patria -de facer imprentar a Historia de Galiza- pero ese compromiso non dependía solo da miña vontade, que nunca faltou, si non en primeiro lugar, que de ahí mandaran os traballos debidamente ordenados, e en segundo lugar que a persoa que aquí se comprometeu a dirixir a impresión cumplira.

¿Si os dous puntos esenciales me fallaron que podía facer eu?

Si co primeiro cumplín poñendo ahí os fondos necesarios para pagos de mapas e colaboradores, co segundo aínda máis, contratando coa imprenta en base a «Maquet» os detalles elaborados polo mismo responsabel-contratado cos clichés etc, a imprenta aboneille a primeira cuota $(\$ 37.500)$ que creo perdida, fixen entrega de todos os materiales que estaban no meu poder, testos, debuxos, mapas, e nada se fixo, a imprenta di que se 
perxudicou coa perda da composición e esixe novo contrato a novos precios, 15 ou 20 veces máis caros, -¿podía eu volver a confiar para contratar de novo cos novos aportes que tamén se perderían?.

Cando vostede estuvo eiquí, dixen eu nunha xuntanza que a Historia de Galiza se faría e dende entonces pasei intres moi amargos, sin saber que facer, -a parte de ahí pensei que podía remediarse pero- ¿cómo resolver o de aquí, si pensaba que o sucedido tocaba os bordes de un sabotaxe?

Polo esposto darase conta dos motivos de non escribirlle, fago oxe ledicioso pola seguridade que teño, de que por fin teremos a Historia de Galiza -gracias á vontade, capacidade e patriotismo de un gran galego, que enterado das dificultades con que eu me encontraba, ofreceuse patrioticamente, a encargarse el, de correr cos traballos da impresión, estoume referindo a Don Luís Tobío.

Comprenderá vostede a tranquilidade que oxe enche o meu espritu, -e a alegría que teño en comunicarlle a vostede esta novedade.

O 12 de Nadal fumos a Montevideu, Prada, Abraira e eu levándolle a Don Luís Tobío todo o material que tiña no meu poder -incluso debuxos e mapas-e, ó por alí en orden as cousas, notamos que, o seu traballo non está completo, e decir que na imprenta ou en outra parte estraviaron algunhas follas últimas, [...]

Infórmolle que a Don Luís Tobío lle din amplios poderes para tratar con vostede e con todos os colaboradores e facer baixo a miña responsabilidade económica todo o que sexa necesario ó seu parecer para terminar a impresión da Historia de Galiza, de maneira que en adiante todo o que Don Luis resolva ou ordene ten a miña conformidade ${ }^{28}$.

Aos problemas que demoraron a saída dos primeiros volumes refírese, de novo, M. Puente nunha carta a Álvaro Gil, na que lle dá conta da asunción por parte de Tobío do coidado da impresión:

${ }^{28}$ Carta de M. Puente a Otero Pedrayo (04/01/61). 
Escríbolle oxe polo siguinte; A Historia de Galicia que vostede estará enterado me comprometín a facer imprentar, e que xa debía estar circulando, está recién nos seus comenzos, e será realidade polo menos nos dous primeiros tomos, que é o único material que hasta agora enviaron da terra, e esto vai a ser posible gracias ó concurso de Don Luís Tobío, que sabedor das dificultades en que eu me encontraba por falla da persoa que se había comprometido a dirixir a impresión, se ofreceu a correr el con ese traballo -e polo tanto se está comenzando a imprimir en Montevideo ${ }^{29}$.

A esta demora e aos problemas coa imprenta fai referencia Otero Pedrayo cando lle escribe a Tobío: «Eiqui os colaboradores desconfían da pubricación. Soio coa saída dun bó volume renascería o entusiasmo». $\mathrm{Na}$ mesma misiva engade: "O interesante é a pronta saída do volume de Etnografía, verdadeira obra prima que xa perde por o moito tempo de agarda» ${ }^{30}$. Aos poucos días, noutra carta: «Estou moi ledo coa nova organización...»; despois de informalo sobre o estado dos traballos, engade: "Compre unha nova organización e moito diñeiro. Por o pronto será gran cousa que saia a Etnografía. [...] Ben sei que D. Manuel gastou en balde moito diñeiro, debeu ser ouxeto de algún engano nas imprentas» 31 .

Aos poucos meses Otero volve expresarlle a Tobío as súas inquedanzas sobre o proxecto: "Eiqui os colabouradores da "Historia" pensada por Manuel Puente mañifestanse esceuticos, procuran non falar do problema quizais para non magoarme a min. En tantos anos a Etnografía -non penso no Introito xeográficopoido ter dado bos froitos e ergueito o nome galego en todo o mundo culto» ${ }^{32}$. O desacougo non desaparece e de novo exprésao: "Quixera saber canto tempo. Eiqui domina a preguiza. [...] Eiqui os mais desconfían coa longa demora» ${ }^{33}$.

\footnotetext{
${ }^{29}$ Carta de M. Puente a Álvaro Gil (04/05/61).

${ }^{30}$ Carta de Otero a Tobío (03/02/61).

${ }^{31}$ Carta de Otero a Tobío $(11 / 02 / 61)$.

${ }^{32}$ Carta de Otero a Tobío $(11 / 05 / 61)$.

${ }^{33}$ Carta de Otero a Tobío (30/07/61).
} 
O que realmente vería a luz foi a «Introdución á Historia». Unha década despois publicarase o tomo dedicado á «Prehistoria», polo tanto o primeiro volume en verdade acaído á denominación Historia de Galiza. Mais o proxecto estaba deseñado e, en parte, en marcha. Otero escríbelle a Tobío:

Sin falar por hoxe dos orixinais en poder de Vde voulle manifestar o estado do traballo: a) feita, con ben poucos engadidos e notas por Xaquin Lourenzo, a Prehistoria por o inesquecente Cuevillas; b) feito un volumen enteiro de historia das Pelerinaxes dende as orixes deica hoxe por D. Xesús Carro; Vde. sabe seu caraiter, quixo traballar soio; c) de Idade Media por Ferro e por mil listas de fontes no Arquivo Histórico Nacional cuias papeletas eu gardo; d) de Idade Moderna tamén moita nota de fontes. Pro hai que esculcalo todo ben dreitamente ben pagando fotocopias. Hai tamén moitas fontes de outros arquivos. De época celto-román di Bouza ter traballado moito; quedamos en que a Outa Idade Media a fixera Ferro e a Baixa Ferro ou Filgueira, facendo dende logo Filgueira a poesía medieval. Non sei si comprirá. Chamoso Lamas fará, non o dubido, a historia d-Arte. Eu quedeime co XVIII e XIX, fora da cultura, e traballo moito. Coido que en dous anos podo ter rematados os dous volumes. ¿E o demais? ¿Que se mete no XVI e XVII? $?^{34}$.

Polo que se desprende do escrito de Otero están rematados nesa altura dous tomos máis: o da Prehistoria de Cuevillas e o das Pelerinaxes de Carro. Os demais traballos estaban en fase de elaboración, encargados ou comentados cos máis importantes especialistas (Ferro Couselo, Filgueira Valverde, Chamoso Lamas, Bouza Brey). Outro dos que andaba a traballar nunha colaboración para a Historia era Aquilino Iglesia Alvariño. A morte sorprendeuno, a el e a todos; dálle novas Otero:

${ }^{34}$ Carta de Otero a Tobío (11/02/61). 
Están abraiados coa morte supeta de Aquilino Iglesia Alvariño. Estiven con el o 27 en Sant Iago, tan bon e ledo e bebedor. Morreu o 28 cando xa eu estaba eiqui. Xa o libro ten que levar unha necrolóxica: Hai que procurar quen faga a historia da lingoa para publicar polo comén da Idade Media. Quizais Isidoro Millán.

Así pois, dos tres volumes que foron editados dentro do proxecto, Tobío coidou dos dous primeiros. Seguramente lle gustaría ser tamén o editor da «Prehistoria» do seu amigo Cuevillas, a quen coñecera nos tempos do Seminario de Estudos Galegos. Cuevillas e Tobío mantiveran nos anos da ditadura de Primo de Rivera unha forte relación epistolar, tanto por ser Tobío o secretario do Seminario e Cuevillas director da Sección de Prehistoria como por ser ambos os que establecían os contactos clandestinos entre os galeguistas. $\mathrm{O}$ texto de Cuevillas $^{35}$, anotado e corrixido por Xaquín Lorenzo, cun engadido de Taboada Chivite, será publicado como terceiro tomo en 1973.

Tanto Puente como Prada procuraron que Tobío coidase da edición do volume da «Prehistoria» de Cuevillas, segundo se desprende da carta de Francisco Fernández del Riego:

Escríboche agora istas liñas para tratar do terceiro tomo da «Historia de Galiza». Dixéronme Prada e D. Manuel Puente que ti ten encarregarías da edición, como fíxeche cos outros dous volumes.

O texto do tomo xa está rematado. Abrangue 362 folios, mecanografiados sobre o orixinal manuscrito que deixou Cuevillas, e 90 máis que escribiu Xesús Taboada Chivite como apéndice e posta ó día. Hai tamén fotos e dibuxos prá ilustración. Pero sería comenente que ti dixeses sobre pouco máis ou menos, a cantidade deles que se necesita.

Si aínda estás disposto a te facer cárrego do traballo, escríbeme decíndome o que debo facer. ¿Queres que che remese xa o material, ou tencionas faguer antes algunhas xestiós nas imprentas, recabando presupostos, etc.? Fico pendente das túas novas ${ }^{36}$.

\footnotetext{
${ }^{35}$ Cuevillas falecera o 30 de xullo de 1958.

${ }^{36}$ Carta de F. del Riego a Tobío (22/09/67). Arquivo Lois Tobío.
} 
Daquela Tobío xa levaba tempo residindo en Madrid, un tanto desconectado dos círculos galeguistas e inmerso nos seus estudos das cartas de D. Diego Sarmiento de Acuña, primeiro conde de Gondomar.

O 29 de outubro de 1962 presentábanse oficialmente os dous primeiros volumes nun acto que tivo lugar no salón de plenos do Centro Galego de Bos Aires, no que participaron, ademais do mecenas Manuel Puente, Abelardo Estévez e o presidente do Centro Galego, Villamarín Prieto, segundo recolle A Nosa Terra ${ }^{37}$. $\mathrm{Na}$ nova xornalística sublínase a presenza de representantes de diversas entidades culturais arxentinas así como de todas as entidades galegas de Bos Aires e Montevideo amais do delegado do Consello de Galiza, Xesús Canabal. No acto, Manuel Puente referiuse en diversas ocasións a Castelao: «que me ensinou a me sentir patriota galego integral [...] espertou na miña conciencia as obrigas que se sinten coa patria [...]. E foi asín que ises anceios se concretasen na decisión de promover e patrociñar que se fixera a gran historia de que carescia a nosa patria Galiza». Segundo conta Tobío, Manuel Puente comezaba así a cumprir a promesa que lle fixera a Castelao nos seus últimos días ${ }^{38}$. Malia os esforzos non poderá rematar a tarefa.

$\mathrm{O}$ acto de presentación coincidiu cos preparativos para o regreso de Tobío e a súa familia a Europa, aproveitando a oportunidade que lle brindara un traslado dentro da empresa farmacéutica na que traballaba. Despois de pasar por Basilea, sede do grupo farmacéutico, recolle á familia en Barcelona (Nadal de 1962) para establecerse en Madrid. Sabemos tamén que a obra estaba publicada dende había algúns meses pois Otero escríbelle dende Ourense o 27 de setembro de 1962: «Estaba en Santander cando chegaron os dous volumes» ${ }^{39}$, aínda que os exemplares aos que se refire don Ramón estaban sen rematar, como aclara Tobío nunha carta a Puente ${ }^{40}$ : «Tiven carta de Don Ramón. Está entusiasmado vendo

\footnotetext{
${ }^{37}$ A Nosa Terra, Bos Aires, no 506, Nadal de 1963.

${ }^{38}$ Sobre a promesa de M. Puente a Castelao, ver Tobío, L.: As décadas..., p. 573.

${ }^{39}$ Carta de Otero a Tobío (27/09/62).

${ }^{40}$ Carta de Tobío a M. Puente (08/10/62).
} 
rematada a edición. O exemprar que levou (incompreto) Meilán, vírono Piñeiro, Lorenzo e outros». Outro dos autores, Xaquín Lorenzo, comunícalle a Tobío: "A fins do vran viñen dende Lobeira a Ourense para ollar os dous primeiros volumes da Historia de Galiza que tés ao teu cargo» ${ }^{41}$.

Na mesma nota de $A$ Nosa Terra á que fixemos referencia recóllese un cariñoso reproche: «Sin querer botar soma algunha encol deste feito tan importante para a cultura galega, desexamos dicir que ben se pudo facer ademais, unha edición mais económica para unha difusión maior da devandita Historia». A recriminación non deixa de ter certa lóxica, aínda que o que os impulsores do proxecto pretendían era facer realidade a primeira gran publicación da cultura galega, tamén dende o punto de vista das técnicas editoriais. Unha grande obra en canto a contido, pero tamén en deseño, edición, ilustración etc. A que «xa foi chamada a "Grande e Xeneral Estoria" en palabras de Otero» ${ }^{42}$. A carestía da publicación tamén preocupaba a M. Puente:

Respeto á composición en corpo 12/12, e certo que sería mellor pero debemos considerar si a obra non se encarecería demasiado, con todo o que hai que agregarlle, refírome ó precio que vai a resultar para a venda que é o que me está preocupando, [...] deixo entón que vostede resolva o que lle pareza ${ }^{43}$.

\subsubsection{Os contidos}

O tomo I consta dun «Prólogo» e un longo capítulo de "Xeografía», autoría de Otero. A «Xeoloxía» é obra de Isidro Parga Pondal, mentres que Luís Iglesias Iglesias achega un capitulo único dedicado á "Xeografía fito-zoolóxica». Risco elaborou o capítulo, con moito, máis extenso, denominado «Etnografía. Cultura

\footnotetext{
${ }^{41}$ Carta de X. Lorenzo a Tobío (03/10/62).

42 Carta de Otero a Tobío (11/02/61).

43 Carta de M. Puente a L. Tobío (04/05/61).
} 
material». O volume remata cunha análise da música e da danza, da que é autor Emilio Pita.

Pola contra o tomo II é obra dun só autor, Xaquín Lorenzo, aínda que se pode considerar continuación do capítulo de Vicente Risco. Ambos os autores tratan de etnografía, Risco desde a vertente cultural e Xaquín Lorenzo dende a óptica da cultura material.

A achega de Otero definitivamente denominouse "Xeografía», a pesar de que insistira en que non debería titularse dese xeito: "Vai a concrusión do prólogo xeográfico. Pois iso e non Xeografía é o meu traballo» ou «Devólvolle o esquema xeográfico. Coido que vai ben. Trátase de un limiar xeográfico e non dunha xeografía. E concedín moito as chamadas de ríos e da costa». Mesmo co exemplar na man seguía pensando que: «Houbera gostado millor que a miña parte levara o tiduo do que é: "Introducción xeográfica”. Máis leente avisado decatárase deseguido» ${ }^{4} 4$.

O grande apartado do primeiro tomo é «Etnografía. Cultura espiritual» de Vicente Risco, profusamente ilustrado con cen figuras, entre fotografía e debuxos, ademais de catro pranchas en cor que reproducen motivos decorativos de colchas e mantas. Entre os debuxos, un de Castelao, outro de Carlos Sobrino, varios de Risco, outros de Xaquín Lorenzo. Entre as fotografías, algunhas de Xosé Suárez.

A achega de Risco á Historia de Galiza constitúe a grande obra etnográfica do pensador ourensán. As claves interpretativas da etnografía risquiana cómpre buscalas na escola histórico-cultural xermana de Graebner e Schmidt e, xa que logo, afastado tanto do socioloxismo francés (Durkheim, Mauss) coma do difusionismo americano (Boas), e preto, na concepción que non no método, do evolucionismo decimonónico de Tyler ou Morgan.

$\mathrm{Na}$ «Expricadeira previa» coa que Risco comeza o seu traballo di:

\footnotetext{
${ }^{44}$ Carta de Otero a Tobío (27/09/1962).
} 
A cultura popular está constituída por elementos, deica certo punto, elaborados polo pobo, e por elementos sedimentados do saber erudito de tempos antigos, conservados polo pobo. Componse igualmente de elementos «indíxenas» (enxebres) e de elementos alóxenos «aculturados», ou sexa incorporados ao que nos é propio. Deiqui vén o seu valor como fonte da historia, por atoparnos nela o que chaman supervivencias de tempos antigos, como si foran verdadeiros fósiles espirituás que o historiador pode estudiar en vivo, porque, a diferencia dos outros fósiles, son materia viva e actuante.

E engade:

En todo caso, o estudo da cultura popular constitui unha ciencia de carácter histórico, que, a un tempo, é unha das ciencias auxiliares da historia, e unha discipliña independente. O seu método tén que ser - sin adscribirnos por esto a ningunha escola- o histórico-cultural. Niste traballo, no que o cadro da cultura popular galega hase presentar como fonte da historia, non se trata de facer un estudio etnolóxico, sinón, como acabamos de decir, un cadro etnográfico que axude dalgún xeito á expricación da nosa historia; non hemos expricar, sinón sinxelamente describir ${ }^{45}$.

$\mathrm{O}$ estudo da cultura espiritual que fixo Risco anuncia o segundo tomo da "Historia», o inmenso traballo sobre a cultura material que realizou o seu discípulo e amigo Xaquín Lorenzo «Xocas» e que abrangue a totalidade do volume. Tamén profusamente ilustrado (514 imaxes) con fotografías e espléndidas ilustracións do gran debuxante que foi Xaquín Lorenzo.

Tobío entendeu que debería tratarse, aínda que fose de xeito breve, o aspecto musical, xa que non o facían nin Risco nin Xaquín Lorenzo. Foi este o motivo que o levou a solicitar de Emilio Pita unha achega sobre o tema. Deste xeito incorporouse o traballo do autor do primeiro libro en galego da posguerra ${ }^{46}$ ao

\footnotetext{
${ }^{45}$ Risco, V.: «Etnografía. Cultura espiritual», en Historia de Galiza, tomo 1, Bos Aires, 1963, pp. 256-257.

${ }^{46}$ Pita, E.: Jacobusland, Bos Aires, 1942. Ilustrado por Castelao.
} 
remate do primeiro tomo e como parte do terceiro apartado da «Etnografía. Cultura espiritual», despois das páxinas que Risco lle dedica á literatura e ás artes plásticas; indicativo da concepción de traballo colectivo e da intervención decisiva de Tobío como editor.

Pita, emigrante en Bos Aires dende neno, escríbelle a Tobío:

Os amigos Prada e Puente, déronme traslado dos teus deseos de que podería redactar un pequeno traballo encol da música popular galega, para engadir á Historia de Galicia que, gracias ao teu derradeiro esforzo, sairá axiña.

Como comprenderás á noticia non deixou de encherme de satisfacción; e a carón desa satisfacción a dúbida de si as miñas cativas condiciós son de abondo capaces, para figurar xunto as outas persoalidades que tratan os principales temas de dita Historia. Creo sinceiramente, que hai na Terra, e fora dela, que pode faguer ese traballo moito millor que eu; por eso creo que nesta oportunidade pesou á túa amical estimanza hacia a miña persoa, tantas veces posta de manifesto e que agradezo en todo canto val. Agora ben, si ti crées que á miña colaboración pode servir de algo, non terei mais remedio que acatar a túa decisión.

Si a túa resolución é definitiva, aínda que os amigos Puente e Prada, déronme a lér unha nota túa onde eispresas o que estimas comenente, breve e conciso ${ }^{47}$.

Por diversos motivos Emilio Pita tivo que demorar o traballo, o que de novo atrasou a edición. En febreiro de 1962 escríbelle a Tobío: «No prósimo mes de Marzo, decidín tomarme unhas vacacións (fai anos que non disfroito delas) e aproveitar ese descanso para dar cumprimento a tan difícil compromiso. Si é posíbel que podas agardar para entón agradeceríacho moito» ${ }^{48}$. Tobío agardou e Pita cumpriu co seu traballo: «Dúas liñas para informarche que este fin de semán agardo termiñar o traballo e mandarcho axiña; estou sacando tamén copia

\footnotetext{
${ }^{47}$ Carta de Pita a Tobío (02/10/61).

${ }^{48}$ Carta de Pita a Tobío (13/02/62).
} 
dos exempros musicaes que engadirei a algunha ilustración que xa teño arredada e espero sirvan» ${ }^{49}$, e aos poucos días: «Escríboche estas letras para comunicarche que a fin de semana vindeira, [...] viaxarei a Montevideo, e entregareiche persoalmente o traballo encol da música, e ti verás si sirve» ${ }^{50}$.

Finalmente o traballo estaba preparado e Pita envíalle a Tobío unha agradecida carta:

Chegou as miñas máns a túa carta tan cordial do día 7 , aledándome moito que atoparas axeitado o meu traballo, inda que ben sei que nas túas verbas hai decote exceso de loubanzas para mín.

Podes, dende logo, introducir no traballo as modificacións de forma e ordenación que atopes necesarias; todo canto ti fagas tén á miña aprobación.

Logo do que xa vin da Historia, estou convencido de que fará «historia» na laboura cultural galega, e neste caso, fora de Galicia. Por eso que a Terra, e todos nós, débenche fonda gratitude, pola tarefa que botaches enriba de ti ${ }^{51}$.

\subsubsection{Deseño, maqueta e ilustraciónns}

A maqueta e o deseño da publicación encargoulla Tobío a Leopoldo Nóvoa (Salcedo, Pontevedra, 1919, Nogent-sur-Marne, 2012). O pintor e muralista - mural do estadio do Cerro de Montevideo (1963) e da canteira do parque de Santa Margarida da Coruña (1989) - pontevedrés trasladárase, ao remate da guerra, coa súa familia ao Uruguai, país do que o seu pai fora cónsul para Galiza. É en Montevideo onde coñece a Tobío compartindo amizades comúns, entre outras a do pintor uruguaio, de pai catalán, Torres García (1874-1945), quen exercerá ampla influencia, non só pictórica, sobre Leopoldo Nóvoa, como el

\footnotetext{
${ }^{49}$ Carta de Pita a Tobío (06/04/62).

${ }^{50}$ Carta de Pita a Tobío (17/04/62).

${ }^{51}$ Carta de Pita a Tobío (13/05/62).
} 
mesmo recoñece ${ }^{52}$. Tobío é un entusiasta da pintura e mantivo relación con moitos artistas plásticos (o citado Torres García, Plastchek, Guréwitsch ${ }^{53}$, os galegos dunha e outra beira do Plata, Colmeiro, Seoane, Laxeiro, Díaz Pardo etc.). No «atelier, [...] unha miga ao xeito da bohemia parisina», en palabras de Tobío, que tiña Nóvoa, no primeiro piso do antigo Mercado Central de Montevideo, lembrado polo pintor como «o taller máis entrañable que tiven» ${ }^{54}$, pasaron ambos «seráns lediciosas a parolar de mil cousas» 55 .

Con anterioridade, como dixemos, Tobío encargáralle a Nóvoa a realización do programa de man do I Congreso da Emigración. A relación entre os dous mantívose ao longo do tempo pero foi especialmente intensa, dende o punto de vista epistolar, nos primeiros meses de 1962. Entre marzo e abril daquel ano crúzanse unha serie de cartas sobre as tapas e sobrecubertas da Historia.

O 21 de marzo de 1962 Leopoldo Nóvoa escríbelle a Tobío:

Doble fue la alegría de vuestra carta, porque, además, me trae el encargo de las tapas para la Historia de Galicia. [...] Respecto a las tapas o sobre-cubiertas, me pondré de inmediato con ellas y te las enviaré tan pronto «encuentre» las que me satisfagan. [...] Por mi trabajo no cobraré precio alguno y te agradezco me hayas asociado a tu labor. Todo lo demás está clarísimo y tus descripciones son suficientes para poder relacionar las sobre-cubiertas con el contenido de cada tomo.

Deseguido refírese ao seu traballo en París e anuncia que vai regresar pronto xa que «me están acosando para que vuelva cuanto antes para realizar los grandes murales del estadio del Cerro» pero que «mi hábitat definitivo seguirá siendo

\footnotetext{
52 Verbo desta cuestión e en xeral sobre a análise da obra pictórica de Nóvoa, ver Sánchez Suárez, C. (2000): Leopoldo Nóvoa en Artistas galegos. Pintores. Posguerra (abstraccións-figuracións), Vigo, Nova Galicia Edicións, pp. 62-103. [Dispoñible en http://leopoldonovoa.com/].

${ }^{53}$ Guréwitsch fixo un retrato de Tobío.

54 Sánchez Suárez, C.: op. cit., p. 67.

55 Tobío, L.: op. cit., pp. 571-2.
} 
París» e coida que «en poco tiempo podré mantenerme de mi pintura sin mayores problemas». A mensaxe remata cunha agoniante reflexión política:

No hablaré de la situación política porque me apena lo que tendría que deciros. La guerra de Argelia ha terminado de «apodrecer» todo y aunque uno se dá cuenta que la crisis es de todo este pequeño Occidente, al que se le viene el mundo encima, creía que Francia podría tener algunas reservas. Y no las tiene porque no hay nada digno de salvarse. Ca-y-est! ${ }^{56}$

Á volta de correo, Tobío envíalle algúns datos sobre as sobrecubertas e os textos das tapas e lombos dos dous tomos e proponlle que sexan independentes dos títulos que poderían ir impresos enriba e en negro, que lle indique o tamaño, a localización e os tipos. Infórmao tamén de que a imprenta que vai facer o traballo é a de Barreiro ${ }^{57}$. Antes de rematar Tobío coméntalle:

Aunque tu negativa a recibir una retribución por tu trabajo es digna de reconocimiento y de encomio, te ruego que cambies de opinión. Por razón de principios conviene que la gente sepa que el trabajo artístico e intelectual debe ser remunerado ${ }^{58}$.

Ao día seguinte $(28 / 03 / 62)^{59}$, polo tanto antes de recibir a carta de Tobío, Nóvoa xa lle estaba escribindo con instrucións para as sobrecubertas:

Ahí te las mando sin esperar por los datos que te pedí sobre la tipografía que irá titulando cada tomo. Por lo que se de ti como persona que estas en la pomada (es decir en cosas de impresiones) sabrás manejarte con los espacios.

\footnotetext{
${ }^{56}$ Carta de Nóvoa a Tobío (21/03/62).

57 Os dous tomos realizáronse na imprenta Barreiro e Ramos S.A., empresa fundada en 1871 por un emigrante galego de Laracha.

${ }^{58}$ Carta de Tobío a Nóvoa (27/03/62).

${ }^{59}$ Carta de Nóvoa a Tobío (28/03/62).
} 
Logo fai unha serie de consideracións: sobre a situación do número de cada tomo «al rente en el ángulo inferior derecho», sobre o título e os subtítulos etc. As cartas de Nóvoa desprenden sempre un fino humor. Nesta á que nos referimos, ao saírenlle un chisco tortas as liñas, despois de lle pegar uns recortes cos tipos de letra, remata cun «Coño, que torcido estaba el papel», non sen antes dar unha proba máis do seu desprendemento: «No tengas ningún temor en decirme que no te gustan, si no te gustan. Ni tengas ningún empacho en no utilizarlas, si fuera así».

O 2 de abril ${ }^{60}$ Nóvoa escríbelle con novas indicacións que: «Ça fait rien, pois ti poderás arrancharte con el asunto de los espacios». Remata: «os teus argumentos o respeito do prix me parecen atendibles. Digamos $\$ 500$.- Si es mucho 400.-, si sigue siendo mucho 300.- y así sucesivamente. Ça-y-est!» ${ }^{61}$. Nóvoa comenta que é domingo e que vén de Chartres, e adherido á misiva envíalle unha tiriña rectangular cun fermoso debuxo en cor dunha das célebres vidreiras góticas da catedral desta vila francesa.

Tobío, nun escrito do 11 de abril de 1962, cualifica os orixinais como «estupendos» e indícalle que: «Tomo nota de tus indicaciones técnicas [...] todo lo cual seguiré estrictamente, dentro de lo posible» e remata con certa nostalxia irónica: «Un abrazo a la Victoria de Samotracia y un beso a la Olimpia de Manet que deben andar por ahí» ${ }^{62}$. Tobío, dilixente, cumpriu as indicacións de Nóvoa.

Os dous tomos están profusamente ilustrados. No primeiro, na sección de «Xeografía» de Otero Pedrayo (respectamos as súas denominacións) incorpóranse planos das sete cidades e dunha serie de vilas: Monforte de Lemos, Betanzos, Cambados, O Carballiño, Celanova, Mondoñedo, Muros, Noia, Padrón, Redondela, Ribadavia, Santa Marta de Ortigueira, Tui, Verín, Viana do Bolo e Vilalba; en total 24 planos. Ademais a sección está ilustrada cos 29 mapas que

\footnotetext{
${ }^{60}$ Carta de Nóvoa a Tobío (02/04/62).

61 Sobre a remuneración do traballo Tobío conserva no seu arquivo copia da orde de pago.

${ }^{62}$ Carta de Tobío a Nóvoa (11/04/62).
} 
se relacionan: Miño Outo, Rexión de Lugo, Sarria e Samos, Rexión de Lemos, Miño Central, Baixo Miño, Rexión da Fonsagrada, Rexión de Becerreá, Rexión de Valdeorras, As Medas, Rexión de Celanova, A Limia, Val Verín, Costa de Lugo, Rexión de Mondoñedo, Ría de Viveiro, Ría de Santa Marta, As Mariñas, Ría da Cruña, Val de Bergantiños, Ría de Corme e Laxe, Cabos Touriñán e Fisterra, Ría de Muros e Noia, Val do Ulla, Rexión de Sant-Iago, Ría de Arousa, O Lérez, Ría de Vigo.

Don Ramón ficou contento coa cartografía: «É grande e boa a ilustración cartográfica» ${ }^{63}$; «Penso que a cartografía é do millor» ${ }^{64}$. Asemade, non deixa de achegar novas ideas: "Cicais estaría ben unha bibliografía xeográfica de Galiza» e insistir na pretensión de incluír un mapa completo de Galiza. Este mapa xa fora realizado pero extraviarase, como lle comunica Puente a Otero: «Tamén nos falta o mapa xeral de Galiza [...] ainda temos a espranza de que SEOANE o encontre, sin embargo teño moita duda de que apareza» ${ }^{65}$. Otero volve co tema do mapa e achega unha solución: «O mapa grande vaise demorar moito. ¿Qué tal unha boa fotografía do venerable Fontán?» ${ }^{66}$.

A lea do mapa foi boa. Puente escríbelle a Tobío: «En canto ó mapa creo que mellor sería facer intervir a Alvaro Gil que foi o que lle abonou ó cartógrafo que os fixo, que é de Madrid ${ }^{67}$. Nesta mesma data Puente escríbelle a Álvaro Gil sobre a cuestión do mapa:

[...] e como ó por en orden os materiales nos topamos en que se estraviou o mapa xeral de Galiza que foi feito xunto con os rexionales ou comarcales por un cartografo de Madrid cuxo nome non sei, e como creo que vostede lle abonou mais ou menos 60.000 Pesetas e saberá quen é -o molesto para rogarlle me faga o favor de encargarlle a

\footnotetext{
${ }^{63}$ Carta de Otero a Tobío (03/02/61).

${ }^{64}$ Carta de Otero a Tobío (30/07/61).

${ }^{65}$ Carta de M. Puente a Otero Pedrayo (04/01/61).

${ }^{66}$ Carta de Otero a Tobío (03/02/61).

${ }^{67}$ Carta de M. Puente a Tobío (04/05/61).
} 
confección- de outro mapa xeral igual ó anterior lle abone o que sexa e remita a brevedade posible directamente a Don Luis TOBÍO a MONTEVIDEO ou a mín ${ }^{68}$.

Ao mes seguinte Prada dille a Tobío sobre a carta a Gil: «non recibín contestación, e comeza a preocuparme, voulle a repetir a carta» ${ }^{69}$.

Cara ao remate do ano, don Ramón segue insistindo na necesidade de incorporar un mapa completo de Galiza: «Para o grande mapa de Galiza compre saber o formato do volume. Si me di con xusteza as dimensións e outras notas de acomodamento mándase facer ó Instituto Geográfico pedindo diante presuposto» ${ }^{70}$. Nesas datas Puente informa da cuestión do mapa a Tobío:

[...] o están facendo en Madrid coa intervención de «BEN CHOSEI», de maneira que como creo que irá pegado, sería bén que para non retrasar o traballo na encuadernación puxeran un papel doblado no lugar correspondente, para ser remplazado logo polo mapa, pois vai a tardar porque o cartógrafo estaba fora de Madrid, este novo mapa vai costar 40.000 Pesetas $^{71}$.

En xaneiro de 1962 Puente cóntalle que «o mapa xeral de Galiza xa está pedido a Madrid e $\mathrm{Vd}$. verá si convén ou non agardar por el» ${ }^{72}$.

A ilustración deste primeiro capítulo completouse con 43 imaxes fotográficas de paisaxes ou vilas das que Otero tamén se preocupaba: "Mire si fai falla algunha fotografía máis, por exemplo de Vigo» ${ }^{73}$ ou «Mandarei unha presa máis de fotos» ${ }^{74}$. Tobío ${ }^{75}$ tiña un bo amigo que lle ía facilitar o labor, o allaricense

\footnotetext{
${ }^{68}$ Carta de M. Puente a Á. Gil (04/05/61).

${ }^{69}$ Carta de M. Puente a Tobío (17/06/61).

${ }^{70}$ Carta de Otero a Tobío $(05 / 11 / 61)$.

${ }^{71}$ Carata de Puente a Tobío (16/11/61).

72 Carta de Puente a Tobío (10/01/62).

73 Carta de Otero a Tobío (03/02/61).

${ }^{74}$ Carta de Otero a Tobío (30/07/61).

75 Ver Tobío, L.: As décadas..., pp. 615-616.
} 
Xosé Suárez, quen naquela altura residía en Punta del Este, e pediulle a súa colaboración:

[...] tengo necesidad de conseguir buenas fotografías de paisajes, pueblos y también algunos monumentos de nuestra tierra para la historia de cuya edición me he encargado. Estas fotografías están destinadas principalmente a ilustrar la primera parte de la introducción que es una síntesis geográfica escrita por Otero Pedrayo. [...] Mucho te agradecería que me pudieras proporcionar este material que sin duda tienes en abundancia. No sé como podríamos selecionarlo pues, seguramente, debes tenerlo casi todo en negativos. Tal vez podría dejarlo a tu buen criterio (20 o 30 fotografías serían suficientes $)^{76}$.

Suárez cumpriu coa demanda e cara a finais do mes seguinte escríbelle a Tobío:

Perdóname si non che mandei as fotos tan pronto como eu houbera querido. Problemas de papel, e de selección no meu caótico archivo, motivaron un pequeno retraso. Espero que che sirvan de algo, o que non será pouco, porque non é posible encarar un traballo como iste, sin un plan previo, e sin pensar, ó facer as fotos, que han cumprir unha misión concreta como a que a ti che encomendaron ${ }^{77}$.

Entre xullo e agosto de 1961 Tobío andou á procura de imaxes coas que ilustrar a «Historia». Na busca de ilustración tamén colaboran os de Bos Aires, Puente escríbelle:

Mándolle un sobre con fotos, etc. entregadas a Prada por Seoane; e todo o que lle deu con encárrego de llas devolver -creo que apenas si lle servirán algunhas; estámonos ocupando de conseguir outras; pois un tal Hermida trouxo unha película de Galiza e

\footnotetext{
${ }^{76}$ Carta de Tobío a Xosé Suárez (28/07/61).

${ }^{77}$ Carta de X. Suárez a Tobío (27/08/61).
} 
díceme que tamén ten fotos- e un aficionado cineasta de La Plata tamén fai algúns anos espuxo boas fotografías, estamos ocupándonos de buscalas e mandarllas dentro duns días; o patronato de Turismo Español dicen que ten boas postales de Galiza, aquí non poidemos conseguir nada, ¿podería vostede ver si a representación de ahí lle facilita algo?78

Nesa altura Tobío andaba tamén atarefado coa correccións das probas: «Alégrome saber que xa comenza a correxir as probas de imprenta do primeiro tomo» dille Puente no mesmo escrito. D. Manuel segue co seu labor e aos poucos días escríbelle de novo: "oxe fumos con Prada a ver unha colección de varios miles de fotos de Galicia que ten o Sr. Hermida sacadas por el na terra, tratase de un ourensán aficionado a ese arte. Separamos 106 (e decir separounas Prada) consideradas axeitadas» ${ }^{79}$.

Neste labor de proporcionar fotografías ao editor tamén participa Fernández del Riego:

Hoxe mesmo, por correo aéreo certificado, mandeiche unha coleición de 42 fotos de paisaxes, vilas, etc. Algunhas delas coido que son boas. Podes escoller as que mellor che parezan. Andiven de cabeza para as precurar, valéndome dunha xente e doutra. Si me tiveras concedido algún marxe de tempo, seríame máis doado conseguir series $\operatorname{completas}^{80}$.

\subsubsection{Obra rematada}

Os dous primeiros tomos da Historia estaban para o prelo. O maior relevo teríao a «Etnografía», que constituía tomo e medio. Otero insistía sempre en que se publicase o traballo de Risco, pois «O Risco xa non traballa mais que en cousas

\footnotetext{
${ }^{78}$ Carta de M. Prada a Tobío (26/06/61).

${ }^{79}$ Carta de M. Prada a Tobío $(29 / 06 / 61)$.

${ }^{80}$ Carta de F. del Riego a Tobío (28/07/61).
} 
literarias» ${ }^{81}$, «O Risco está vello e doente» ${ }^{82}$ ou «O Risco non está hoxe para traballos serios» ${ }^{83}$, da publicación don Ramón agardaba un efecto recuperador: «O traballo de Risco ten valeiros. O Risco xa non está para traballos fortes. Peteira lixeiramente en materias literarias e deixase levar por a vontade. Si a Etnografía saír o nome de Risco voltaría ó seu verdadeiro rango» ${ }^{84}$.

O recoñecemento dos traballos etnográficos publicados vai ser importante entre os especialistas. Tobío conservou unha serie de cartas cruzadas co etnolingüista alemán Fritz Krüguer ${ }^{85}$, que daquela dirixía o Instituto de Lingüística da Universidade de Cuyo en Mendoza, interesándose polos traballos de Risco e Xaquín Lorenzo e anunciándolle que:

Estoy preparando un trabajo sobre "La cultura popular y dalectología en España», contribución a la Enciclopedia de Lingüística Hispánica del CSIC de Madrid, Tomo II.

Pienso que sería muy oportuno presentar y aprovechar en esta ocasión los trabajos de V. Risco y J. Lorenzo. Desearía tener alguna noticia, a la brevedad posible, sobre la aparición de estos artículos ${ }^{86}$.

Tobío envíalle os traballos e Krüguer, nunha extensa carta escrita ao día seguinte de recibilos, dille:

No puedo expresar en pocas palabras la profunda impresión que recibí al hojear y examinar las páginas de esta extraordinaria obra. Uno de los días más felices de mi vida ha sido éste, en que veo terminada la obra del amigo Lorenzo Fernández y en buena marcha

\footnotetext{
${ }^{81}$ Carta de Otero a Tobío (03/02/61).

${ }^{82}$ Carta de Otero a Tobío $(11 / 02 / 61)$.

${ }^{83}$ Carta de Otero a Tobío $(30 / 06 / 61)$.

${ }^{84}$ Carta de Otero a Tobío $(11 / 05 / 61)$.

${ }^{85}$ Krüguer (1889-1979) foi un dos grandes dialectólogos do século XX e realizou traballos sobre distintas áreas lingüísticas da Península Ibérica, tamén sobre o galego e áreas limítrofes. Fora profesor da U. de Hamburgo e director do Seminario de Filoloxía Románica, onde fundou a revista Volkstum und Kulter der Romanen. En 1948 trasladouse á Arxentina e exerceu na U. de Cuyo ata a súa xubilación.

${ }^{86}$ Carta de Krüguer a Tobío (29/06/62).
} 
la del amigo Risco [Tobío aínda non puidera enviarlle todo o traballo]. Verdaderamente es difícil decir lo que hay que admirar más: la enorme diversidad del material, la exactitud perfecta de la descripción, la excelente documentación gráfica o la presentación. En todos los aspectos la obra es magnífica, un modelo de trabajo que honra a todos los colaboradores y a Galicia. Además, ¡los recuerdos personales que encuentro a cada paso...! La vida y cultura gallega revividas, en grata coincidencia, en el artículo que sobre la casa rural publicara Lorenzo Fernández primeramente en alemán en la revista hamburguesa «Volkstum und Kultur der Romanen», hace más de 20 años.

Felizmente puedo comprender y valorar todo lo que encierra la modesta aclaración que aparece al final: «A edición estivo ó coidado de Lois Tobío».

Mis más sinceras felicitaciones a todos, al mecenas que subvencionó la obra, haciendo así posible una publicación de tanta envergadura, a los colaboradores especialistas de primer orden en su materia, a los que debieron enfrentarse con los arduos problemas técnicos de la impresión y que tan airosamente los han resuelto. Sin duda, pocas regiones de España cuentan con una publicación tan bien documentada y presentada.

Voy a mandar copia de esta carta que en forma concisa expresa mis aplausos, a los señores Puente, Prada, Lorenzo Fernández, Vicente Risco y Otero Pedrayo ${ }^{87}$.

A continuación pídelle permiso para poder reproducir algunhas ilustracións no traballo que anunciaba para o CSIC, recomenda engadir unha bibliografía ao final da obra e comprométese a publicar «reseña o reseñas sobre la Historia de Galiza, no sé todavía si en España, EE. UU. o Alemania (en una revista de etnografía general); por lo tanto me interesa saber si la obra ya ha salido en la Ed. Nós».

Tobío escríbelle anunciando que pronto lle poderá mandar o que falta do traballo de Risco, que non hai problema para reproducir as ilustracións que necesite, que a saída do prelo é inminente polo que se pode referir a ela como xa

${ }^{87}$ Carta de Krüguer a Tobío (31/07/62). 
publicada, agradecéndolle ademais as favorables opinións xa que «la opinión de quien, como Ud. es alta autoridad en la materia, resulta invalorable» ${ }^{88}$.

O remate do traballo desata as emocións. Otero escribe a Tobío ${ }^{89}$ :

Meu querido e lembrado amigo e irmán:

Unha aperta calada e fonda, unha das meirandes e verdadeiras do meu vivir vai pra Vde nista folla. Estaba en Santander cando chegaron os dous volumes. Faloume deles Ramón Piñeiro con grave entusiasmo. Fai dous días camiño por eles. Como polo Valadouro ou a Mahia. O peito alenta en ámbito esteso: soia de pazo, cráustro, paisaxe, ría. Medrou un souto oután. Fai pequenos os demais matos e arboredas. Inda non podo facer unha estimación ouxetiva. Soio testemuñar miña admiración e respeto diante a laboura de Vde facendo no arsenal e peirao do seu traballo e entusiasmo que os dous navíos saíran o mar libre.

Un novo tempo na historiografía de Galiza. Un libro, dous, non do ano. De moitos anos como autoalidade. Algo de menhir ou castro ordeados de infindos remuíńos.

Houbera gostado millor que a miña parte levara o tiduo do que é: Introducción xeográfica. Mais léente avisado decatárase deseguido. Non deixa quezais de ter un senso o feito de ter nado os tres autores, cada un na sua xeneración, nun seitor curto da rúa da Paz, de Ourense, a menos de 15 metros os berces mais desviados un do outro.

Saudos na casa e ós amigos. Sempre o vello irmán agradecido, emozoado.

O outro dos autores nacido na rúa da Paz tamén lle escribe a Tobío con non menos fonda emoción:

Meu querido irmán: Moito tempo fai que non sei directamente de ti, anque teño noticias por tua irmá â que vexo de cotío eiquí.

De todos os xeitos un deber de gratitude faime agora escribirche.

\footnotetext{
${ }^{88}$ Carta de Tobío a Krüguer (21/08/62).

${ }^{89}$ Carta de Otero a Tobío (27/09/62).
} 
A fíns do vran viñen dende Lobeira a Ourense para ollar os dous primeiros volumes da Historia da Galiza que tés o teu cargo. Vín o meu traballo e vín tamén a tua man amiga níl. Sei do traballo que che tivo que dar e o ben que de íl saíches. Deus cho pague.

Esta tua colaboración connosco trouxome âs mentes as nosas angueiras no Seminario de estudos galegos e lembrei aquiles tempos que xa non voltarán. Entón aínda había cordialidade no mundo e hoxe somentes podemos vivir de aquelas lembranzas.

De novo que Deus cho pague.

Recibe unha aperta moi forte do teu amigo e irmán ${ }^{90}$.

\section{O mesmo entusiasmo manifesta Fernández del Riego:}

Vimos, todos os amigos, os dous exemprares da «Historia» que trouxo Meilán. Produxeron en cantos tiveron ocasión de os follear, unha fonda impresión. Dende logo, trátase de algo sen precedentes na nosa bibliografía. A presentación ten empaque, feitío estético, e unha elegancia tipográfica destacadísimas. Debo felicitarte, sinceramente, polo enorme esforzo que realizache, con evidente intelixencia e bó gusto ${ }^{91}$.

Como é evidente, o máis emocionado ao poder ter entre as súas mans os dous primeiros tomos foi o mecenas da obra, quen lle escribe dous días antes da presentación pública:

Non me é fácil narrar a emoción que me produxo os dous tomos da Historia de Galicia que me enviou por Abraira, cando os foliaba parecíame ver as mans de Castelao facendo o mesmo, e ó cerrar os libros dixen para mín «Xa podo MORRER», o meu compromiso coa patria quedará cumplido.

Pasei moitas angustias, ó ver que os anos transcurrían sin que comenzara a imprentarse a Historia, chegando a temer que a vida non me alcanzara a vela, hasta que supen que

${ }^{90}$ Carta de X. Lorenzo a Tobío (03/10/62).

${ }^{91}$ Carta de F. Fernández de Riego a Tobío (17/11/62). 
vostede aceptaba encargarse de dirixir a impresión, dende entonces calmáronse as miñas dudas e oxe podemos mostrar ó mundo esta maravilla, non somentes polo seu contido si non tamén pola categoría da presentación que vostede lle deu. Por todo elo querido Don Luis reciba as miñas felicitacións xunto co meu eterno e patriótico agradecemento, coa seguranza que no correr da historia a nosa patria fará xusticia a este seu esforzo patriótico.

O día once do corrente fixose eiqui unha cea que os patriotas quixeron dedicarme con motivo da Historia, puxose de manifesto toda a laboura sua, acordando enviarlle un telegrama co agradecemento dos presentes (que coido os organizadores lle haberán mandado), os reunidos eran 50 ou 60 -a maioría dirixentes do centro galego, cuxa xunta había antes tomado conocemento da obra en sesión especial- enviáronme unha carta moi conceptuosa.

Don Ramón escribeume moi emozoado, dime que non é «o libro do ano, é de moitos anos».

Aquí llo enseñamos a Don Salvador de Madariaga -quedou maravillado ${ }^{92}$.

Vinte días antes Tobío enviáralle a Puente unha carta coa relación dos pagamentos realizados, cos seus xustificantes, así como daqueles pendentes e mais dos que el mesmo debería atender directamente. E remata: «Estou satisfeito de cómo quedou este traballo. [...] Hai que agradecer da Ude. Que tan xurdía empresa poidera ter realidade. É grande a honra que coela se lle fai á Nosa Terra» ${ }^{93}$.

\section{UN FÍO EN DIAGONAL}

Fernández del Riego, nunha das cartas ás que fixemos referencia (22/09/67), facíalle unha petición: «¿Por qué non me envías algúns traballos teus para

\footnotetext{
${ }^{92}$ Carta de M. Puente a Tobío (27/10/62).

${ }^{93}$ Carta de Tobío a M. Puente (08/10/62).
} 
"Grial"? Algo terás por ahí que servirá para publicar na revista». Á demanda respondeu Tobío en positivo. Envioulle un ensaio breve titulado «O nomeamento de Gondomar como embaixador en Londres» que vería a luz no número 24 de Grial $^{94}$, no ano 1969.

Tobío, asentado en Madrid, andaba enguedellado nas cartas do arquivo de don Diego Sarmiento de Acuña, para satisfacer aquela inquedanza que corenta e tantos anos atrás espertara nel o seu profesor Ciríaco Pérez de Bustamante, quen:

[...] tiñase interesado pola figura do Conde de Gondomar ao ter atopado documentación encol da súa actuación nos intentos de Walter Raleigh en América. Presentou verbo deso unha comunicación no Seminario de Estudos Galegos e máis adiante tratará tamén o tema no discurso inaugural do curso 1928-1929 na universidade que lle corresponderá facer. Estes traballos espertarán en min a arela de afondar no estudo deste gran diplomático noso e esa arela poderá ser cumprida moitos anos despois...95

Comezara a súa asidua visita sabatina á Biblioteca de Palacio ou Real Biblioteca, como nos conta a súa filla Constanza:

Durante largos años desde que venimos a vivir a Madrid los sábados por la mañana iba siempre a la Biblioteca del Palacio Real y volvía con unas cuantas fichas escritas con su

\footnotetext{
${ }^{94}$ A revista Grial, da que turraba con esforzo proletario Fernández del Riego, publicou as seguintes colaboracións de Tobío sobre o conde de Gondomar: «O nomeamento de Gondomar como embaixador en Londres», tomo VII, núm. 24, 1969; «O erasmismo de Gondomar», tomo VIII, núm. 28, 1970. «Gondomar e o galego», tomo XI, núm. 40, 1973; «Outras dúas cartas en galego a Gondomar», tomo XV, núm. 57, 1977; «A amistade de Bacon e Gondomar», tomo XVIII, núm. 68, 1980, e «Galego familiar escrito a comenzos do século XVII», tomo XVIII, núm. 69, 1980. A Fundación Otero Pedrayo, con motivo do Premio Trasalba que lle concedeu en 1991, publicou unha recompilación dos artigos de Grial baixo o rótulo de Catro ensaios sobre o Conde de Gondomar, no que se recollen os traballos sobre o nomeamento como embaixador, o erasmismo e a amizade con Bacon e se refunden baixo o título «Actitude verbo da lingua galega» os outros.

${ }_{95}$ As décadas..., p. 120.
} 
cuidadosa caligrafía que incorporaba a unas cajas de zapatos a modo de fichero. Asi se fue fraguando su inmensa relación con Gondomar.

Notas que lle servirían para ir armando os seus libros sobre don Diego Sarmiento de Acuña. O primeiro verá a luz en 1974 baixo o título de Gondomar y Raleigh. Tobío recorda con emoción, en As décadas, que á presentación do libro no Museo de América de Madrid acudiu o seu vello profesor Pérez Bustamante, quen dixo no acto palabras de emocionada lembranza.

Tiven o pracer de argallar a publicación do seu derradeiro libro sobre don Diego, Dous embaixadores: Digby e Gondomar, que publicamos no Instituto de Estudos Miñoráns en 2005. A copia do mecanoescrito entregáranola don Lois nunha das visitas que lle fixeramos, na súa casa madrileña, poucos anos antes. A complexa versión ao galego realizouna a profesora María Xosé González Chamorro, lembrada compañeira e amiga que xa non se encontra entre nós ${ }^{96}$.

Aquela primeira visita, no ano 2001, serviu para pedirlle autorización para que o auditorio de Gondomar levase o seu nome. A saúde xa non lle permitía achegarse ata a vila do conde. O 26 de novembro de 2005, nunha sesión de honra que tivo lugar no auditorio Lois Tobío, a corporación municipal de Gondomar acordou recoñecelo como fillo adoptivo. Un sente certa fachenda cando escoita as amizades ou a familia dicir que van ver ou escoitar tal ou cal cousa ao Lois Tobío. En Gondomar non se di «vou ao auditorio», senón «vou ao Lois Tobío».

Esta familiaridade, esta identificación parece a resposta natural da veciñanza ante quen se refería, e non só nas conversas senón tamén nos escritos, a Diego

\footnotetext{
${ }^{96}$ A obra "gondomareña» completa de Tobío é: Gondomar y su triunfo sobre Raleigh, Santiago, Bibliófilos Gallegos, 1974; A intervención de Gondomar nos problemas internacionacionais de pesca, Sada (A Coruña), Ediciós do Castro, 1984; Gondomar y los católicos ingleses, Sada (A Coruña), Ediciós do Castro, 1987; Dous embaixadores: Digby e Gondomar, Gondomar, Instituto de Estudos Miñoranos, 2005.

Ademais dos publicados en Grial xa citados, ten outro artigo: "Cuestiones de precedencia en la Corte inglesa durante la embajada se Gondomar», Revista de Estudios Internacionales, abril-xuño, 1984.
} 
Sarmiento de Acuña non polo seu nome, ou por don Diego, nin por conde de Gondomar, nin sequera por conde, senón simplemente por Gondomar. Nesta identificación con Sarmiento de Acuña había tamén unha querenza profesional e nostálxica: Tobío vira truncada a súa carreira diplomática tras a guerra española e non recuperará o seu posto ata 1974, dous anos antes de xubilarse. Era o grao de identificación tan absoluto que precisaba ese ton familiar, próximo, persoal. Reafírmanolo a súa filla Constanza:

A ello hay que añadir otros amigos como el Rey Jacobo, la Reina Ana, Digby, Constanza de Acuña, Bacon y otros tantos junto a los que tan buenos ratos pasó. En cuanto a Gondomar, la identificación es tan grande que en un momento de confidencias me confesó sentirse como la misma persona, «al fin y al cabo», añadió «los celtas creemos en la reencarnación».

Tobío referiuse en moitas ocasións a que, lendo a correspondencia do conde, ás veces preguntábase sobre que respondería sobre tal ou cal asunto; despois decatábase de que aquilo que el pensara que ía ser a resposta de Gondomar, efectivamente así era. Tobío teceu un sutil fío que une Viveiro con Gondomar; unha diagonal, como a denominou o profesor Villares na súa gabanza de Tobío cando foi recoñecido como fillo adoptivo de Gondomar, entre a vila mariñá e a miñorá.

Mais non entendamos a súa dedicación a Gondomar só como unha simple aproximación a un colega diplomático ou un esforzo de erudición, vexamos na fortaleza da dedicación tobiana a Gondomar a identificación co coidado das flores propias do xardín galego, pois Galiza, para Tobío, non só era un mundo, senón que estaba no mundo.

Atrévome, coa liberdade que permite non ter que decidir, a propoñer para xa un Día das Letras, co seu ano, para Lois Tobío e, insistindo no meu atrevemento, que ese día e ese ano fose unha festa conxunta para Tobío e Gondomar. Así os méritos excesivos de Tobío para tal recoñecemento poderían minorar as posi- 
bles tachas que alguén, con limitada perspectiva, lle puidese apoñer a Gondomar. Estou seguro de que a Tobío lle encantaría a idea. Precedentes de celebracións compartidas hai.

\section{RAMO}

Sempre me chamou a atención a estraña afección, no ámbito da cultura e da política galegas, ao libro de conversas en contraste co máis ben escaso cultivo do texto autobiográfico ou «libro de memorias». En especial, é salientable a afección por este xénero(?) entre os líderes políticos. Nada que dicir. Só que este tipo de receitas, subliñando de antemán que nalgúns casos se recollen magníficos ensaios en resposta a atinadas preguntas, parten dun inocente engano, perpetrado, coa aquiescencia da persoa entrevistada, polas persoas entrevistadoras.

Pola contra andamos máis ben escasos de relatos autobiográficos. Algúns deles, en especial no caso dos políticos, non son máis que simples alegacións en defensa propia, Noutras ocasións, o libro de memorias non pasa de ser un exercicio de orgullo desmedido.

Pero o que é rara avis no noso mundo cultural son os textos memorialistas entendidos como un exame de conciencia exercitado co auxilio da memoria, compañeira falaz e traidora de nós mesmos, capaces de relacionar os acontecementos autobiográficos coas experiencias sociais, civís, éticas e morais, ou de reflexionar sobre estas cuestións dende a propia experiencia persoal sen renunciar á lectura crítica das propias decisións persoais ou actitudes xeracionais. Non son precisas Confesións rousonianas senón unha actitude ética ante o papel que procure evitar as flagrantes ausencias, as evidentes contradicións e os pavoroso silencios. Como a ausencia non é total, ben poderiamos dar algún exemplo máis, sobre calquera deles sobrancean As décadas de T. L.

De novo batemos co Tobío que dende o encanto da discreción, dende a actitude de apertura ideolóxica e psicolóxica, dende a sinxeleza de tripar camiños, 
sabe colocar o ramo na construción que ergueu para grandeza da casa común. As memorias de Lois Tobío é un deses libros que dignifican calquera literatura por esixente que sexa e ao tempo é unha lección de historia e, por riba de todo, e cómpre telo moi presente, unha lección moral e de paixón pola vida; ao cabo, como o mestre: «Wie es auch sei, das Leben, es ist gut». 